\title{
The Usefulness of Financial Accounting Information: Evidence from the Field
}

\author{
Stefano Cascino \\ London School of Economics \\ s.cascino@1se.ac.uk \\ Mark A. Clatworthy \\ University of Bristol \\ mark.clatworthy@bristol.ac.uk \\ Beatriz García Osma \\ Universidad Carlos III de Madrid \\ bgosma@emp.uc3m.es \\ Joachim Gassen \\ Humboldt-Universität zu Berlin \\ gassen@,wiwi.hu-berlin.de \\ Shahed Imam \\ University of Warwick \\ shahed.imam@wbs.ac.uk
}

Running Head: The Usefulness of Financial Accounting Information

\begin{abstract}
* We thank Markus Arnold, Mary Barth (senior editor and discussant), Ulf Brüggemann, Christina Dargenidou (discussant), Matt Hall, Kevin Jackson, Peter Joos, Guy Jubb, Laurence van Lent (editor), Victor Maas, Stephen Taylor (discussant), Geoffrey Whittington, Stephen Zeff and participants at the 2016 BAFA Annual Conference, 2015 EAA ICAS Symposium, 2016 EAA Annual Congress, IASB-ICAS Meeting on the Future of Financial Reporting, 2015 EUFin Conference, XII Workshop on Empirical Research in Financial Accounting, University of Amsterdam, University of Bath, University of Bologna, BI Norwegian Business School, Cardiff University, Columbia Business School, ESSEC Business School, University of Essex, Ghent University, University of Glasgow, Heriot-Watt University, Humboldt University Berlin, ICJCE/AT1 Madrid Meeting, IFASS Toronto, Keele School of Management, King's College London, Lancaster University, LUISS Business School, Magdeburg University, University of Manchester, Mannheim University, Open University, Portsmouth University, Universidade de São Paulo, University of St. Gallen, Stockholm School of Economics, Strathclyde University, Tilburg University, National Taiwan University and University of Technology Sydney for helpful comments and discussions. We acknowledge the financial support of the Scottish Accountancy Trust for Education and Research, Institute of Chartered Accountants of Scotland (ICAS) and the European Financial Reporting Advisory Group (EFRAG). Beatriz García Osma acknowledges financial assistance from the Spanish Ministry of Science (ECO2016-77579 and PID2019-111143GBC33). Joachim Gassen acknowledges financial support from Deutsche Forschungsgemeinschaft-Project-ID 403041268 - TRR 266. A summary of the first phase of this study intended for an audience of practitioners has been circulated by ICAS and EFRAG under the title 'Professional investors and the decision usefulness of financial reporting.' We are grateful to Michelle Crickett, Françoise Flores, Saskia Slomp, Rasmus Sommer and Allister Wilson, who provided invaluable assistance for this project. Ethical approval for this project was granted at the University of Bristol. Finally, we acknowledge the contribution of Thomas Jeanjean to the earlier phases of our study. Any remaining errors are our own.
\end{abstract}

Correspondence to: Mark Clatworthy, School of Accounting and Finance, University of Bristol, Priory Road Complex, Bristol, BS8 1TU, U.K. E-mail: mark.clatworthy@bristol.ac.uk. Tel. +44 1173941479. 


\title{
The Usefulness of Financial Accounting Information: Evidence from the Field
}

\begin{abstract}
We examine how investment professionals assess the usefulness of financial accounting information depending on their information acquisition objectives and preparers' earnings management incentives. We conduct a survey experiment based on face-to-face interviews with investment professionals and document two main results. First, we find that, compared with investment professionals assigned a firm valuation objective, those assigned a managerial performance evaluation objective assess accounting information as significantly less useful. Second, we find no systematic evidence that preparers' earnings management incentives negatively affect investment professionals' assessments of accounting information usefulness. To elucidate this second finding, we conduct a large-scale follow-up online experiment. Our results continue to offer no support for the effect of earnings management incentives on investment professionals' assessments of accounting information usefulness, irrespective of preparers' corporate governance quality. Instead, we find that poor corporate governance, by itself, reduces the usefulness of accounting information to investment professionals.
\end{abstract}

Keywords: decision usefulness; financial reporting objectives; earnings management; corporate governance; investment professionals; relevance; representational faithfulness.

JEL Classifications: G15, G18, G38, M41, M48. 


\section{INTRODUCTION}

Do investment professionals assess the decision usefulness of financial accounting information depending on what they aim to use the information for? Also, are their assessments influenced by preparers' earnings management incentives?

These questions are at the core of fundamental and enduring debates among accounting regulators and academics. Financial reporting is meant to fulfil two main information acquisition objectives - a valuation objective and a managerial performance evaluation or stewardship objective (Beyer, Cohen, Lys, and Walther 2010). Over time, however, the conceptual frameworks of major accounting standard setters have subsumed valuation and stewardship within a single 'decision usefulness' objective, even though general purpose financial statements may not be capable of satisfying multiple objectives simultaneously (Murphy, O'Connell, and Ó hÓgartaigh 2013; Zeff 2013; Pelger 2016). These developments have also largely overlooked the wellestablished view in the academic literature that using financial reporting information for contracting creates earnings management incentives (Watts and Zimmerman 1986). Yet, relatively little is known about the extent to which earnings management is actually pervasive (Ball 2013) and undermines the decision usefulness of financial accounting information.

The theoretical literature offers important insights on our two questions. With regard to the first, Gjesdal (1981) demonstrates that an accounting system designed for valuation purposes generally differs from one designed for managerial performance evaluation. For managerial performance evaluation, information should enable investors to assess managers' unobservable effort (Harris and Raviv 1978; Holmström 1979). In contrast, for firm valuation, information should help predict the timing, amount, and risk of future cash flows, regardless of whether they are attributable to managerial effort (Paul 1992; Guttman 2013). Regarding the second question, 
prior theoretical research shows that preparers' earnings management typically decreases the informativeness of accounting information, though the ultimate effect is harder to predict when markets form rational expectations (Stein 1989), and when models account for various features of firms' corporate governance systems (Goldman and Slezak 2006; Laux and Laux 2009).

Only few empirical studies explore the effects of users' information acquisition objectives on accounting information usefulness. This limited empirical research fails to document a conflict between the different roles of accounting information (e.g., Bushman, Engel, and Smith 2006; Banker, Huang, and Natarajan 2009). These studies are predominantly based on observational data, mainly rely on indirect proxies of information usefulness, and typically employ crosssectional identification strategies. In contrast, a vast empirical literature documents associations between earnings management incentives and financial accounting properties (e.g., Healy and Wahlen 1999; Dechow, Ge, and Schrand 2010). In particular, starting with Healy (1985) and the bonus plan hypothesis of Watts and Zimmerman (1986), there is overwhelming support for the idea that bonuses linked to accounting information increase the likelihood of earnings management, with very few voices challenging this conventional view (Ball 2013).

In this paper, we provide novel evidence on how investment professionals assess the decision usefulness of financial accounting information. We conduct a survey experiment based on 81 faceto-face interviews with experienced investment professionals from 16 countries to directly elicit their views on information usefulness through both quantitative assessments and verbal responses. We present investment professionals with the abridged financial statements of a fictional firm and manipulate: (i) their information acquisition objectives (i.e., firm valuation or managerial 
performance evaluation); and (ii) preparers' earnings management incentives (i.e., whether or not managerial compensation in the case firm is tied to accounting information). ${ }^{1}$

While the small sample of our survey experiment enables us to gauge the specific rationales underlying investment professionals' information usefulness assessments with precision, it also limits statistical power. Further, while our survey experiment allows us to focus on investment professionals' assessments of usefulness, it does not allow us to observe how our treatments affect their actions. To alleviate both concerns, we examine investment professionals' behavior directly via a large-scale follow-up online experiment.

In our second experiment, we task a subject group of 833 investment professionals with the selection of income statement line items to construct an adjusted earnings measure. The task-based nature of this experiment enables us to evaluate how the assessments documented in our first experiment relate to actions in the second. While the quality of the case firm corporate governance system is held constant in the survey experiment, we take advantage of the larger sample size of the follow-up online experiment and manipulate, along with earnings management incentives, the quality of the case firm corporate governance system as well. This enables us to examine whether stronger corporate governance arrangements mitigate investment professionals' potential information usefulness concerns when managerial compensation is tied to earnings (Laux and Laux, 2009). We expect our two-pronged approach to improve the external validity of our findings (Bloomfield, Nelson, and Soltes. 2016).

Taken together, our experiments yield several key results. First, compared with investment professionals assigned a firm valuation objective, those assigned a managerial performance

\footnotetext{
${ }^{1}$ Throughout the paper, we refer to 'earnings management incentives' as shorthand for whether the managers' compensation in the case firm is tied to accounting or non-accounting data. Our aim is to evaluate investment professionals' assessments of accounting information usefulness when this key determinant of earnings management behavior varies.
} 
evaluation objective assess accounting information as significantly less relevant. In line with theoretical predictions, when evaluating managerial performance, investment professionals prefer accounting numbers that are informative of managerial actions to those potentially affected by factors outside managerial control. In contrast, for firm valuation, investment professionals prefer information that is relevant for forecasting future cash flows. These results indicate that information acquisition objectives affect the extent to which investment professionals assess accounting information as useful. This confirms theoretical predictions and helps to balance prior empirical evidence based on observational data.

Second, when we experimentally increase earnings management incentives by linking managerial compensation to accounting data, we find no evidence that it affects either information usefulness assessments or the actions of investment professionals. Our follow-up online experiment reveals that this result is not due to a lack of statistical power and does not depend on the corporate governance quality of the case firm. Subject to the potential limitations of our experimental design, this finding is at odds with much of the theoretical and empirical literature suggesting that earnings management incentives are a pervasive problem in capital markets (e.g., Stein 1989; Graham, Harvey, and Rajgopal 2005). However, it is in line with recent skepticism over the pervasiveness and significance of earnings management (e.g., Ball 2013).

Third, while we find no evidence that the effect of earnings management incentives depends on corporate governance quality, we also show that, when corporate governance quality is poor, investment professionals are significantly less likely to use accounting numbers over which managers have more discretion.

Our study makes several contributions. Drake, Hales, and Rees (2019) provide initial crosssectional evidence on the task-dependent nature of information usefulness assessments. By using 
an experiment to identify causal determinants of investment professionals' information usefulness assessments, we show that the usefulness of financial accounting information is contingent on users' information acquisition objectives (Anderson, Brown, Hodder, Patrick, and Hopkins 2015; Brown, Call, Clement, and Sharp 2015). Thus, our findings contribute to the debate on whether a single set of general-purpose financial statements can simultaneously satisfy potentially competing user needs (Drymiotes and Hemmer 2013; Murphy et al. 2013; Zeff 2013; Pelger 2016).

Our examination of the extent to which preparers' earnings management incentives affect either investment professionals' information usefulness assessments or decisions advances the long line of research that weighs the incentive alignment benefits of managerial discretion over accounting numbers (Sloan 1993; Ball 2001; Lambert 2001; Kothari, Ramanna, and Skinner 2010) against the associated costs (Watts and Zimmerman 1978; 1986; Healy 1985; Holthausen, Larcker, and Sloan 1995; Goldman and Slezak 2006; Crocker and Slemrod 2007; Dichev, Graham, Harvey, and Rajgopal 2013).

Finally, by showing that—despite their inherent limitations—-financial statements remain a primary information source for investment professionals, our novel descriptive evidence contributes to the literature on the importance of financial statements vis-à-vis other sources of information (Ball and Shivakumar 2008; Beyer et al. 2010; Basu, Duong, Markov, and Tan 2013).

\section{CONCEPTUAL UNERPINNINGS AND HYPOTHESIS DEVELOPMENT}

\section{Decision Usefulness and Information Acquisition Objectives}

The theoretical literature predicts that users of financial statements demand accounting information for both contracting and valuation purposes (Lambert 2001). When evaluating managers, users require information that enables them to separate managerial effort from value-relevant exogenous factors, such as industry and market-wide dynamics (Holmström 1979; Gjesdal 1981; Paul 1992; 
Sloan 1993; Lambert 2001; Christensen, Feltham, and Sabac 2005). In contrast, the valuation role of accounting information is to resolve uncertainty about firms' future cash flows, regardless of whether they are attributable to managerial effort (Paul 1992; Guttman 2013). Although theoretical research indicates that an accounting system designed for firm valuation generally differs from one designed for managerial performance evaluation (Gjesdal 1981), it also identifies conditions under which the two roles of accounting information coincide (Drymiotes and Hemmer 2013).

Empirical evidence on the interactions and trade-offs between different uses of accounting information is scarce (O’Connell 2007; Murphy et al. 2013). Bushman et al. (2006) and Banker et al. (2009) examine the association between the value relevance and the compensation relevance of earnings and reject the null hypothesis that the valuation and contracting roles of accounting are unrelated. However, the indirect proxies for information usefulness they use may not precisely measure the underlying constructs of interest. In a recent web-based survey of information overload in financial reporting, Drake et al. (2019) report that investment professionals' ratings of the importance of financial statements differ depending on the task at hand. ${ }^{2}$ They find that investment professionals rate the income statement and the statement of cash flows as more useful in assessing future cash flows than for most other tasks, whereas the balance sheet is rated as important for assessing credit risk. Taken together, prior empirical work relies mostly on crosssectional identification, says little about why observed associations exist, and cannot reliably establish causal relations.

Prior research also yields conflicting evidence on whether financial accounting information aids managerial performance evaluation. Georgiou (2018) shows that fair value information, which

\footnotetext{
${ }^{2}$ Although the key focus of their study is on information overload, Drake et al. (2019) also analyze six tasks: 'assessing future cash flows,' 'estimating firm value,' 'identifying red flags,' 'evaluating risks and uncertainties,' 'assessing credit risk,' and 'evaluating management.'
} 
is generally regarded as of high relevance, may interfere with analysts' and fund managers' managerial performance assessments. In contrast, Anderson et al. (2015) report that fair value information can sometimes benefit managerial performance evaluation by allowing users to disentangle managerial effort from exogenous market factors. ${ }^{3}$

How useful accounting information is to users with different objectives therefore remains an open, yet fundamental, question. Accounting standard setters decompose the usefulness of accounting information into two fundamental qualitative characteristics: relevance and representational faithfulness (e.g., FASB 2010; IASB 2018). Relevance is defined as the ability of information to influence decision-making, assuming it is faithfully represented. Information is considered to be faithfully represented if it is complete, neutral, and free from errors. We posit that investment professionals regard accounting information as less relevant for assessing managerial performance than for firm valuation. As standard setters calibrate their reporting regimes to focus on information that helps assess the magnitude, timing, and uncertainty of future cash flows (Zeff 2013), our expectation is motivated by theoretical studies that argue that, while an accounting system designed to assess future cash flows produces a useful signal for firm valuation, the same signal may not be as informative about managerial effort. This is because the signal produced by such a system is less informative of whether observed performance is the result of managerial actions or factors outside managers' control. Accordingly, our first hypothesis is:

H1: Investment professionals assess the relevance of financial accounting information to be lower when their objective is to evaluate managerial performance.

While $\mathrm{H} 1$ follows directly from the theoretical literature, it might not fully describe how users assess accounting information according to different objectives. First, prior empirical work based

\footnotetext{
${ }^{3}$ Anderson et al. (2015) do not study differences between valuation and managerial performance assessments and their experimental fair value data are free from measurement uncertainty and bias (Emett and Nelson 2015).
} 
on observational data has generally found that earnings data has a robust positive covariance with both market values and performance proxies, consistent with accounting information being a useful indicator for both information acquisition objectives (Bushman et al. 2006; Banker et al. 2009). Second, under certain conditions, accounting information may produce relevant signals about managerial performance and firm value (Anderson et al. 2015). Lambert (2001) also highlights circumstances where incorporating factors outside managers' control (e.g., relative performance data) can be useful for assessing managerial performance. In such circumstances, we would fail to find support for H1.

\section{Decision Usefulness and Earnings Management Incentives}

Financial accounting information is often used to align the interests of principals and agents in executive compensation contracts (Sloan 1993; Lambert 2001; Armstrong, Guay, and Weber 2010). In these contracts, managerial compensation is determined on the basis of accounting information. A long and influential stream of research documents that managers face incentives to manage accounting information to increase their pay (Watts and Zimmerman 1978; 1986; Healy 1985; Holthausen et al. 1995; Bergstresser and Philippon 2006; Crocker and Slemrod 2007). Goldman and Slezak (2006) demonstrate that incentive contracts act as a 'double-edged sword' by simultaneously increasing managerial effort and encouraging managers to misrepresent performance. While managers may attempt to deceive investors by managing earnings, according to Stein (1989), investors are not misled in equilibrium. ${ }^{4}$

\footnotetext{
${ }^{4}$ Fischer and Verrecchia (2000) discuss circumstances where managerial reporting bias cannot be undone due to capital markets' uncertainties about managers' reporting objectives. In their analysis, managerial bias reduces the informativeness of financial reports. This interpretation is also discussed by Ewert and Wagenhofer $(2005,1115)$, who recognize that research casts doubt on the descriptive validity of the assumption that investors fully understand the quality of financial reporting signals and are able to infer the equilibrium level of earnings management.
} 
We predict that investment professionals' assessments of representational faithfulness depend on whether managers face incentives to manage earnings. Accordingly, we expect that tying managerial compensation to accounting information increases managers' incentives to manage earnings to increase their pay, which, in turn, negatively affects investment professionals' assessments of whether accounting information faithfully represents underlying firm performance. Our second hypothesis is therefore:

H2: Investment professionals assess the representational faithfulness of financial accounting information to be lower when earnings management incentives are higher.

$\mathrm{H} 2$ is a relative test and we acknowledge that earnings management may be affected by a variety of additional factors, including capital market incentives, the quality of accounting standards, audit quality, and firm-level governance (Dechow et al. 2010; Dichev et al. 2013). Extensive prior research shows that features of the corporate governance system, such as board independence, may significantly constrain earnings management (e.g., Klein 2002; Peasnell, Pope, and Young 2005). In a study of the interactions between the various dimensions of board quality, Laux and Laux (2009) demonstrate that, when the earnings-compensation relationship is strong, other features of the corporate governance system adapt to ensure that financial reporting quality is upheld. Moreover, Brown et al. $(2015 ; 2016)$ report that buy-side and sell-side analysts regard corporate governance factors as highly influential over managers' intentional misreporting. ${ }^{5}$ Taken together, these arguments make the expected relation between the use of accounting information in compensation contracts and earnings management unclear ex ante.

\footnotetext{
${ }^{5}$ We specifically examine the interplay between earnings management incentives and corporate governance quality in our follow-up online experiment.
} 


\section{SURVEY EXPERIMENT}

\section{Research Design}

To test our hypotheses, we conduct a between-subject $2 \times 2$ case-based survey experiment. We collect data via face-to-face interviews with experienced investment professionals from 16 countries. We employ a field-based approach, rather than a laboratory experiment with student subjects, because the nature of our research question requires experienced users of financial accounting information. Our theory assumes that users are able to separate managerial performance from exogenous factors - a task that may be challenging for inexperienced users (Emett and Nelson 2015). ${ }^{6}$ We therefore survey experienced investment professionals, who are familiar with both valuation and managerial performance assessments in their professional roles and who represent target users of financial accounting information.

Survey experiments are a common method used to identify the causal determinants of stated preferences, assessments, and beliefs in many fields, including sociology (e.g., Wallander 2009), political science (e.g., Druckman, Green, Kuklinski, and Lupia 2006), and public economics (e.g., Kuziemko, Norton, Saez, and Stantcheva 2015). Compared with traditional surveys, survey experiments mitigate several potential biases, such as treatment-specific selection bias, randomization bias, interviewer bias, and behavioral effects of individuals being aware of their experimental subject status (e.g., List 2011; Clor-Proell, Koonce, and White 2016).

We ask investment professionals to provide assessments of decision usefulness, rather than to perform a specific fictional task (e.g., make an investment, evaluate managers, etc.). ${ }^{7}$ This is

\footnotetext{
${ }^{6}$ Christensen-Szalanski, and Beach (1984), List, Haigh, and Nerlove (2005), and Alevy, Haigh, and List (2007) report that experienced users behave more in line with rational theories of decision making than student subjects.

${ }^{7}$ We focus on objectives rather than tasks building on Gjesdal's (1981) seminal analysis of the distinction between the valuation and stewardship roles of accounting information, that defines objectives (p. 208) as "the reasons [financial reporting information] is demanded." In addition, task performance is inherently hard to observe in an interview setting, where surveying stated hypothetical actions triggered by assigned tasks raises more validity
} 
because the nature of the task would closely relate to the information acquisition objective (i.e., one of our key variables of interest). ${ }^{8}$ In addition, since we gather response data through face-toface interviews with investment professionals, fictional tasks would appear artificial and provide unrealistic incentives. We use a case-based approach to test for the causal determinants of investment professionals' information usefulness assessments. We manipulate: (i) the information acquisition objective of investment professionals, and (ii) the case firm managers' earnings management incentives. ${ }^{9}$

Our survey instrument uses seven-point Likert scales, together with open-ended questions that encourage investment professionals to think aloud while answering. This allows us to ask followup questions to validate the numerical data from Likert scores and to explore investment professionals' rationales for their assessments of usefulness. ${ }^{10}$

The hypothetical situation in our survey revolves around a fictional case of a large European private manufacturing firm. ${ }^{11}$ In the case, investment professionals first read about the firm. We provide a summary balance sheet and annual income statement (see Exhibit 1). We also provide a brief summary of relevant IFRS accounting policies, as well as key areas of management judgment

\footnotetext{
questions than surveying assessments triggered by assigned objectives. This is especially the case for our sample of expert subjects that regularly face heterogenous high-stake tasks.

${ }^{8}$ In their survey, Drake et al. (2019) assess the relative importance of the balance sheet, income statement, statement of cash flows, statement of stockholders' equity, and statement of other comprehensive income across six tasks: 'assessing future cash flows,' 'estimating firm value,' 'identifying red flags,' 'evaluating risks and uncertainties,' 'assessing credit risk,' and 'evaluating management.' This list of tasks exemplifies the difficulty in clearly separating tasks from objectives, and the existence of overlaps between tasks where, for example, identifying red flags would feed back into both evaluating management and estimating firm value.

${ }^{9}$ We design the questions to be case-dependent because we specifically aim to elicit subjects' answers that reflect usefulness assessments conditional on the assigned information acquisition objective and the earnings management incentives inherent in the case. We do this to avoid capturing subjects' general prior beliefs, which are likely to hinge on their backgrounds (e.g., education, professional experience, etc.).

${ }^{10} \mathrm{We}$ include a research ethics and information consent form stating that our research has ethics committee approval. Further details of the development of the survey experiment are available in the Online Appendix. The full survey materials and details of how we code the narratives contained in the interviews and follow-up questions are available in the paper's GitHub repository: https://github.com/joachim-gassen/use fai.

${ }^{11} \mathrm{We}$ choose a private firm to facilitate firm valuation without using publicly observable market prices. This may bias our findings towards an overall higher reliance on accounting numbers for decision-making.
} 
in measuring and recognizing financial statement items. The investment professionals-the subjects of our survey experiment—have highly international backgrounds and are likely to be familiar with IFRS, but not necessarily with different national GAAP regimes. We inform our subjects that a leading audit firm audits the case firm and that corporate governance is externally evaluated to be of high quality (see Exhibit 2). The owners of the case firm are described as a small group of closely cooperating institutional investors that monitor the management of the firm. Explicitly holding these governance characteristics constant helps ensure that any observed effects can be attributed to our manipulation, rather than to implicit assumptions about the corporate governance of the case firm. In our follow-up online experiment, we explicitly manipulate corporate governance quality to examine its effects on information usefulness.

To test $\mathrm{H} 1$, we manipulate the information acquisition objective. Investment professionals are assigned an objective either to 'assess the value of the firm' (the firm valuation treatment), or to 'assess the performance of the management for the current year' (the managerial performance evaluation treatment). To test $\mathrm{H} 2$, we manipulate the presence/absence of earnings management incentives in the case firm, based on whether accounting (or non-accounting) information forms the basis of managerial bonuses. Investment professionals assigned to the accounting-based compensation treatment are provided with the following information on the managerial incentivization system of the firm:

(The current owners) rely on individually negotiated target plans based on financial accounting data for managerial incentivisation. This year, management will receive a generous bonus as they have exceeded their target net income levels.

Investment professionals assigned to the non-accounting-based compensation treatment are told that the firm relies on non-accounting (i.e., internal) data for managerial incentivization:

(The current owners) rely on individually negotiated target plans based on internal production data for managerial incentivisation. This year, management will receive a generous bonus as they have exceeded their target production efficiency levels. 
Taken together, the two manipulations-information acquisition objective and earnings management incentives—-result in four distinct treatment conditions, as per Figure 1.

We ask investment professionals to assess the relevance and representational faithfulness of the accounting information provided. Relevance is described as the ability of the information to influence decision making, assuming that it is faithfully represented. Information is described as faithfully represented if it is complete, neutral, and free from errors. ${ }^{12}$ Despite the separation of the two constructs, it is possible that the subjects conceptually link relevance and representational faithfulness to the extent that, if they perceive an item not to be faithfully represented, they also consider it to be less relevant (Kadous, Koonce, and Thayer 2012). ${ }^{13}$ However, the verbal response data we obtain (below) suggest that our subjects are acquainted with the two characteristics.

The survey is designed to be completed in around 45 minutes and requires investment professionals to assess the usefulness of eight different balance sheet and income statement line items: Revenue, EBITDA, Net income, Property, plant and equipment (hereafter PPE), Financial instruments, Intangible assets (other than goodwill), Goodwill, and Pension liabilities. ${ }^{14,15} \mathrm{We}$ ask our subjects to assess the extent to which these line items are relevant and faithfully represented

\footnotetext{
${ }^{12}$ Our definition of representational faithfulness aims to avoid potential confusion over what the information 'purports to represent.' This latter depiction is more consistent with the high-level definition provided in the IASB Conceptual Framework, but less comprehensible (Erb and Pelger 2015).

${ }^{13}$ Kadous et al. (2012) study MBA students with less experience than the investment professionals in our survey.

${ }^{14}$ We design our survey to be completed in 45 minutes to increase the likelihood of investment professionals accepting our interview invitation.

${ }^{15}$ We choose line items that: (i) are prominent to investment professionals (Gu and Chen 2004; Gassen and Schwedler 2010; Brown et al. 2015; Black, Christensen, Ciesielski, and Whipple 2018); (ii) exhibit variation in managerial discretion, informativeness about managerial actions and firm value, and financial accounting complexity (Drake, Roulstone, and Thornock 2016; Hoitash and Hoitash 2018); and (iii) reflect a tradeoff between feasibility (given time constraints) and generalizability (i.e., the extent to which the informativeness of our line items reflects overall financial statement information). We use both GAAP and non-GAAP line items because prior research suggests that investment professionals make adjustments to GAAP numbers (Kraft 2014), exclude from GAAP earnings items such as extraordinary items, discontinued items, restructuring charges (Brown et al. 2015), and rely on non-GAAP earnings numbers (e.g., Bradshaw and Sloan 2002; Doyle, Lundholm, and Soliman 2003; Black et al. 2018; Bradshaw, Christensen, Gee, and Whipple 2018).
} 
(using a scale from $1=$ strongly agree, to $7=$ strongly disagree). ${ }^{16}$ We also encourage our subjects to explain the factors that are important to them when considering the relevance and representational faithfulness of financial accounting information.

Once investment professionals assess relevance and representational faithfulness, we request that they identify three sources of information besides financial accounting information that are useful for their assigned objective. To assess the relative importance of these alternative sources, we inform our subjects that they have a $€ 100,000$ budget to obtain relevant information. They are then asked to allocate the budget between the three sources they identify, together with a fourth source - that is, improving the usefulness of available accounting information. This provides an estimate of the relative value placed on the different sources of information, given the objective of information acquisition. The survey ends with several open-ended questions.

\section{Sample Description}

To recruit our subjects, we cooperate with the Institute of Chartered Accountants in Scotland (ICAS) and the European Financial Reporting Advisory Group (EFRAG). ICAS and EFRAG initially identify 101 suitable candidates for our study. ${ }^{17}$ From this list, we conduct first-stage pilot interviews with six individuals to finalize our case design and survey instrument. We schedule interviews with 82 investment professionals; of these, one decided not to sign the ethics consent form. The remaining 81 subjects form the basis of our Full Sample. From within this sample, we

\footnotetext{
${ }^{16}$ For the subsequent presentation of the data and results, we recode the scales for ease of interpretation so that higher values indicate higher usefulness. While we use the term 'financial investments' in the case material to communicate the nature of the financial instruments (non-derivative equity) more efficiently, we use the more neutral term 'financial instruments' in the interpretation of the results.

${ }^{17}$ This includes investment professionals recommended to us by ICAS and EFRAG who were eventually unable to participate in the study. Although the involvement of ICAS and EFRAG skews our sample towards investment professionals with more accounting experience, we would have been unable to secure the participation of such a large and experienced sample without their cooperation. It is also common for surveys of experienced capital market participants to cooperate with other organizations to enlist research subjects (e.g., Graham et al. 2005; Elliott, Hodge, and Jackson 2008; Clor-Proell et al. 2015; Dichev et al. 2013; 2016; Reimsbach, Hahn, and Gürtürk 2018).
} 
rely on five subjects to conduct a second-stage pilot to finalize our survey experiment design. As these five subjects receive the same case material and survey as the other subjects, we include them in the Full Sample on which we base our descriptive analyses. These subjects are, however, excluded from the experimental analyses. We also exclude from our main analysis 14 interviews with investment professionals who fail the manipulation checks, to ensure that all subjects are properly treated. ${ }^{18}$ Our Experimental Sample therefore comprises 62 investment professionals, generating a total of 537 verbal responses. Table 1, Panel A, summarizes the sample composition.

Tables 1 and 2 present descriptive statistics for the Full Sample. Unreported analyses of the different samples and treatment conditions reveal no significant demographic differences across treatment groups. ${ }^{19}$ Table 1 reports the distribution by geographic location and age group. The sample mainly comprises investment professionals based in Europe, with the United Kingdom being the most common country in which our investment professionals operate. ${ }^{20}$ The sample also includes subjects based in the United States and Canada, thus constituting a geographically diverse group of investment professionals (Table 1, Panel B). The most frequent age group is 41-45 (25 percent), followed by $46-50$ ( 20 percent), then $36-40$ ( 14 percent). We characterize 45 (56 percent) investment professionals as 'accounting experts' since they either have an accounting degree, or state that their occupational responsibilities involve certain aspects of financial reporting. ${ }^{21}$ Occupational details are reported in Table 2. A substantial number of subjects, 44 (54 percent),

\footnotetext{
${ }^{18}$ In an additional analysis, we document that the likelihood that our subjects fail the manipulation checks does not depend on the type of treatment they receive. We also conduct sensitivity tests in which we re-run our main analyses using a sample containing the 76 observations that receive the final treatment including the 14 subjects that fail the manipulation checks. While the results for this sample are statistically weaker for some tests, the tenor of our findings remains unchanged. The results of our additional analyses are available in the paper's GitHub repository.

${ }^{19}$ These results are reported in the paper's GitHub repository.

${ }^{20}$ The predominance of the United Kingdom reflects both the importance of London as an international financial center and the involvement of ICAS in our study.

${ }^{21}$ Although we have no statistics for comparison, it is likely that this proportion is high due to the involvement of a professional accounting institute (ICAS) and an accounting regulatory body (EFRAG) in identifying our subjects.
} 
consider themselves fund managers, whereas 34 (42 percent) regard themselves as analysts. Of these analysts, 22 (27 percent) are on the sell-side. Consequently, the majority of our investment professionals (56, or 69 percent) have a buy-side focus (Table 2, Panel A). Most of these focus on public equity and have a geographic or industry focus (Table 2, Panel B).

As shown in Table 2, Panel C, our subjects are highly experienced, with an average of 20 years of total experience and nine years of experience in their current position. They regularly follow an average (median) of 61 (35) firms for their investment decisions. For the subcategory of fund managers (Table 2, Panel D), ${ }^{22}$ the mean (median) value of funds under individual management is around $\$ 1.56$ billion ( $\$ 400$ million). These subjects hold an average of 82 different stocks and their average holding period is approximately 3.5 years. Overall, our main sample comprises influential and experienced investment professionals, generally managing sizable investment portfolios, for a reasonably long holding period. Based on these demographics, we are confident that our subjects are familiar with their assigned objectives and are acquainted with the concepts of relevance and representational faithfulness. ${ }^{23}$ Our interviews with the investment professionals provide reassurance that this is the case. For instance, the following quotes illustrate subjects' familiarity with managerial compensation arrangements and with managerial performance assessments: ${ }^{24}$

"When I meet with management, especially a company that seems to be getting into trouble financial trouble - I will ask how they are compensated, because it will help me understand what they are motivated on."

(Fund manager, U.K, Managerial performance evaluation | Accounting-based compensation)

\footnotetext{
2238 of the 44 fund managers provide this information. In some cases, fund managers were part of a team and were unable to state their individual funds under management.

${ }^{23} \mathrm{We}$ are confident that the investment professionals are familiar with both for a number of reasons. First, the vast majority are able to recall their assigned objective and the corporate governance characteristics of the case firm when asked at the end of the interviews. Second, because we conduct face-to-face interviews, the subjects are able to clarify any misunderstandings. However, such clarification questions are rare, indicating that the subjects understand what they are being asked. Third, we test for significant differences in answering behavior across occupational groups and find no qualitative differences.

${ }^{24}$ To enhance readability, quotes are edited to remove stop words (e.g., 'you know,' 'okay,' and similar).
} 
"What I like to do is, you meet the company, you ask them to give you three or four milestones to check next year. Like verbal milestones. "I expect to do this ..." Or it could be: "I see my margins drifting up. I expect these products to become unexpectedly in demand." ... I want [to] come back next year, just look at my notes [and say]: "Okay, you said three things. Did these three things happen? Why? Or why didn't they happen?" And if they happened, then I am always going to kind of give... okay, management said this... so, I am always going to give them the benefit of the doubt."

(Buy-side analyst, U.K., Managerial performance evaluation | Non-accounting-based compensation)

\section{Descriptive Evidence on the Decision Usefulness of Financial Accounting Information}

Table 3 reports the overall assessments of usefulness of different line items by presenting the distributions of scores for relevance (Panel A) and representational faithfulness (Panel B) based on the seven-point Likert score and subjects' verbal responses. ${ }^{25}$ The first three rows of averages (Financial statements (all), Income statement, and Balance sheet) are based on aggregated data for each individual line item. ${ }^{26}$ The verbal responses represent the number of statements explicitly relating to relevance and representational faithfulness for the financial statements overall and for individual line items. These are coded as negative, neutral, or positive. ${ }^{27}$

Panel A shows that investment professionals assess overall financial statement information as highly relevant. It also reveals substantial differences between the income statement and balance sheet in general, and between different line items in particular. Most line items are assessed as highly relevant overall, with income statement components - particularly Revenue and EBITDAassessed as most relevant. In contrast, Intangible assets (other than goodwill) and PPE (measured at amortized historical cost in the case) are not assessed as highly relevant. Although the former

\footnotetext{
${ }^{25}$ One subject did not assign a score to the representational faithfulness of revenue and pension liabilities. Descriptive evidence for the Experimental Sample is available in the paper's GitHub repository.

${ }^{26} \mathrm{We}$ average all responses across balance sheet and income statement line items to form summary measures of information usefulness.

${ }^{27}$ To analyze verbal responses, we rely on a coding manual. In the first step, three coders from the research team separately analyze 33 (40 percent) randomly selected, anonymized interviews using the manual. A number of topics and arguments are identified and classified in this process. The three coders then check each other's coding for consistency across coders. Once a satisfactory level of agreement is reached, the coding manual is finalized. Using this manual, two teams (of two coders each) code all interviews. Then, each coder checks all interviews coded by the other coder from his/her team. Both coders discuss any areas of disagreement and produce a final list of quotes from all 81 interviews. The coding manual and details of the coding process are available in the paper's GitHub repository.
} 
may reflect the nature of the case (manufacturing) firm, this does not explain why PPE receives such low relevance assessments. Panel A reveals no consistent view of Goodwill: Likert scores are almost uniformly distributed across the relevance scale.

Overall, the verbal response analysis confirms the Likert scores, indicating that investment professionals offer more positive than negative rationales to justify their assessment of relevance. Almost 58 percent of responses on relevance (148/256) are coded as positive, with Revenue, EBITDA, and Financial instruments receiving particularly positive verbal responses.

Descriptive statistics for assessments of the representational faithfulness of accounting information are presented in Table 3, Panel B. While they assess accounting information to be faithfully represented overall, numerical assessments are generally lower than for relevance. Moreover, verbal response data present a less positive assessment of representational faithfulness than relevance, with only 28 percent of responses coded as positive. Intangible assets (other than goodwill), Goodwill, and Net income receive particularly low assessments.

Despite its status as arguably the most important accounting figure, no positive verbal responses are offered for the representational faithfulness of Net income. This is consistent with prior literature suggesting that market participants do not rely solely on GAAP earnings (e.g., Bradshaw and Sloan 2002; Doyle et al. 2003). For instance, Brown et al. (2015) indicate that analysts exclude line items such as extraordinary items, discontinued items, restructuring charges, and asset impairments, among others, from GAAP earnings. ${ }^{28}$

A comparison of both panels of Table 3 strongly indicates that investment professionals differentiate between line items according to different measurement bases when assessing the

\footnotetext{
${ }^{28}$ The subtotal nature of Net income and EBITDA could drive the lack of positive verbal responses. These magnitudes are not independent of line items such as Revenue. However, our subjects evaluate income statement line items in descending sequence, and our findings suggest that they evaluate Net income vis-à-vis EBITDA, effectively focusing on the accrual components that distinguish them.
} 
usefulness of accounting information. These results also reveal the value of decomposing the overall concept of 'usefulness' into relevance and representational faithfulness: experienced professional users of financial statements seem quite capable of separating them (cf. Kadous et al. 2012). For example, while $P P E$ is assessed as more faithfully represented than relevant ( $t$-statistic of 5.40), the opposite is true for Financial instruments ( $t$-statistic of 3.76).

We next turn to the verbal response data to explore some of the rationales that our subjects present for their assessments (Table 4). Panel A reports rationales relating to relevance, whereas Panel B presents rationales relating to representational faithfulness. Rationales mentioned more than ten times are reported separately, with all other rationales aggregated into the Other category. The right-most column reports the percentages of positive responses, that is, whether a particular line item is assessed as more relevant or faithfully represented given the rationale provided. ${ }^{29}$

Overall, the ability of the information to assist users in forecasting is the most commonly cited reason for relevance assessments. The following quotes illustrate the (positive and negative) ability of certain line items to assist in this context:

"Because I view EBITDA as one of the key indicators of a business going forward and its ability to generate cash...."

(Fund manager, U.K., Managerial performance evaluation | Non-accounting-based compensation)

"I'm interested ultimately in understanding the returns that the business is generating from the assets that it's got, so if I can think about the cash returns it's going to generate, but then the plant and equipment, there is this CFROI idea where you ought to inflation-adjust your plant and equipment rather than just look at a historical book, so it's more like a kind of replacement cost approach, almost. So that's one reason why I would maybe assign less weight or I'd want to know more information about that plant and equipment, because obviously if it's a historical book value that's going to inflate the returns from that business, I'd want to know how up to date that plant and equipment number was and get it as close to replacement cost as I could."

(Fund manager, U.K., Managerial performance evaluation | Accounting-based compensation)

\footnotetext{
${ }^{29}$ To illustrate, for example, 'Application/Measurement complexity' is mentioned 19 times in the context of relevance (Table 4, Panel A), whereas it is assessed as increasing decision usefulness in only one case (5.3 percent). In all other cases (18 out of 19), it is discussed as reducing it.
} 
"Goodwill I think is far less important because ... it purely provides historical information. Usually, it is very specific acquisitions, which you cannot estimate can be repeated in the future. So I would put it [as] not really relevant."

(Sell-side analyst, Spain, Managerial performance evaluation | Accounting-based compensation)

In line with theoretical predictions, Relevance of information to understand managerial

impact ranks highly in Panel A. The following quotes illustrate this:

[On the relevance of pension liabilities:] "It has nothing to do with the management ... So it's a seven. Irrelevant. [...] It's a very important number, but to assess the management performance I don't think it's relevant. Because, again it could go up ... yields could collapse, yields could increase, assumptions of mortality can change ... None of that really has anything to do with ... how many widgets these guys make and how much profit they make doing it ... a huge number might change and might have nothing to do with management."

(Fund manager, U.K., Managerial performance evaluation | Non-accounting-based compensation)

[On the relevance of net income:] "It is less relevant, because it includes items that are outside the control of management... These not within their immediate control would include taxes, interest, impairments ...."

(Sell-side analyst, Canada, Managerial performance evaluation | Accounting-based compensation)

"Yes, well, I suppose with goodwill it is a historic thing, there is not much the management can really do about that; now it has been spent and it has been done."

(Sell-side analyst, U.K., Managerial performance evaluation | Accounting-based compensation)

Investment professionals do not regard the informational properties of different line items as

'fixed' and often see themselves as able to enhance the relevance of certain line items through their

own adjustments, as the following quotes indicate:

“... when we are looking at annual reports we are looking a lot at the off-balance obligations. And for instance leases we are looking at. Because what we are working on is to make cases comparable. That means that if you had to have two companies who are equal but one of them is buying the property and plant and equipment and the other one is leasing it as operating leases, then in our world we cannot compare them before we have made some adjustments in relation to the $P \& L$ and also in relation to the balance sheet. So, we are looking at the off-balance obligations as well."

(Sell-side analyst, Denmark, Managerial performance evaluation | Accounting-based compensation)

"And I should not feel uncomfortable where I am in a position where I can make the adjustment I want to. So, because the reason why the numbers are presented as they are here, that is the IFRS, that is the standards. So, as long as the standards allow me and the accounts allow me to make the corrections that I want, then, I guess, I should be a happy man."

(Sell-side analyst, Denmark, Managerial performance evaluation | Accounting-based compensation)

Even though our subjects have significant accounting expertise, the complexity involved in

measurement and in the application of accounting standards is assessed to have a negative 
influence on relevance under both objectives. As Table 4, Panel B, shows, however, this complexity is more influential for assessments of representational faithfulness than relevance. It is by far the most commonly cited rationale for the typically low representational faithfulness ratings (90 percent of verbal responses are either negative or neutral). Moreover, a further 30 responses relate to the complexity inherent in the accounting standards themselves. The following quotes exemplify subjects' views of accounting complexity:

"Yes, fair value is an art ..."

(Fund manager, Sweden, Firm valuation | Accounting-based compensation)

"Accounting for financial instruments is really very complicated; it is hard to see the business model of the firm behind financial instruments accounting but it is important."

(Buy-side analyst, Switzerland, Firm valuation | Accounting-based compensation)

"It is again a made-up number, what is goodwill? [...] Despite being an accountant, I still do not know [...] Well, I struggle with the concept of goodwill. And I do not think I am alone in ... I appreciate why it's there, but [...] when you look at a balance sheet, you say: 'What is this?','

(Fund manager, U.K., Managerial performance evaluation | Non-accounting-based compensation)

Given the relatively high level of accounting expertise of our subjects, these views likely represent a 'lower bound' of concerns over accounting complexity in the investment community.

The second-most and third-most presented rationales in Panel B (managerial incentives and compensation) hint at the concerns that investment professionals have with respect to managerial discretion. Numerous quotes indicate an awareness of the potential for earnings management in various circumstances not linked to managerial compensation arrangements, though there is also a degree of acceptance of such behavior.

"In some cases it could be that they want to show weak figures if they are undergoing some sort of inquiry for competitive practices. In other instances, they could be interested in showing strong figures - for instance in a merger process or ... because of the bonuses."

(Fund manager, Norway, Managerial performance evaluation | Non-accounting-based compensation)

"[T] hey'd be fools if they didn't [manipulate earnings] ... and manipulate do I mean they are evil, nefarious people trying to do something? Probably not. But are they human beings who will try to portray things in the best light? Who will exploit the wiggle room that the standards provide to them? Who will exploit the auditors who are happy to look in the other direction with no fault being meant to them either? Yes, they will do all of these things. There will be manipulation, 
perhaps also for good reasons. To avoid stupidities in the standards [...] managers could come up with a better disclosure than what the standard suggests for this company."

(Fund manager, U.S., Firm valuation $\mid$ Accounting-based compensation)

Also, our subjects regularly refer to corporate governance aspects of the case firm, including auditing and external verification, when assessing whether financial accounting data are faithfully represented (recall that the corporate governance system of our case firm is of high quality). The vast majority of the verbal responses reflect confidence that governance mechanisms help ensure representational faithfulness, as the following quotes illustrate:

"If they have strong corporate governance, then the risk that someone manipulates earnings is very low."

(Sell-side analyst, Denmark, Managerial performance evaluation | Non-accounting-based compensation)

"That [pension liability] will be a three. And the reason I have a little bit more faith in this is that they use... with an independent actuarial advice, so they have some sort of external view of that liability."

(Fund manager, Denmark, Managerial performance evaluation | Accounting-based compensation)

Summarizing these findings, there are clear differences in the assessed usefulness across line items. Investment professionals find line items to be relevant when they provide information about the underlying business model and when they help forecast firm activities or evaluate managerial performance. The complexity of measurement and the underlying economics, as well as the complexity of the accounting standards per se, are the main reasons why investment professionals are skeptical about the representational faithfulness of the information. In addition, managerial subjectivity, paired with incentives, is a frequent reason for low assessments.

How do investment professionals rank financial accounting information relative to alternative information sources? We capture this as the relative share that our subjects allocate to financial accounting information out of a hypothetical $€ 100,000$ budget, compared with their three top other non-accounting sources. We ask subjects to specify any three alternative information sources to avoid directing them towards certain categories. Table 5 summarizes the responses. It shows that investment professionals allocate a comparatively high share (34.8 percent) of their budget to 
acquiring and analyzing accounting information. Alternative information sources are manifold. We summarize them into groups and find that alternative quantitative and qualitative information on the business of the firm and competitors captures the largest share. The finding that approximately one third of the information environment of investment professionals consists of accounting information is in line with prior studies (Brown et al. 2015) and indicates that, its weakness notwithstanding, accounting information remains a key input in investment professionals' decision-making.

\section{Test Results}

We test our hypotheses based on univariate tests. Multivariate findings (unreported) in which we also control for subjects' personal demographics and include interviewer and verbal response coder fixed effects confirm our findings. ${ }^{30}$ We test three different types of dependent variables: (i) the line item assessment of relevance (H1) and representational faithfulness (H2), which are evaluated using either Likert scores or the share of positive rationales being stated (Table 6); (ii) the frequency of rationales that support our predicted mechanisms (Table 7); and (iii) the relative share that our subjects allocate to financial accounting information relative to alternative information sources (Table 8). Figure 2 offers a visual representation of our predictions and empirical findings from the survey experiment.

Table 6, Panel A, reports the line item-based test results for the effect of the information acquisition objective (managerial performance evaluation or firm valuation) on the assessed relevance of financial statement line items. As predicted by H1, overall, investment professionals assigned a firm valuation objective assess financial statements as significantly more relevant than those assigned a managerial performance evaluation objective. This result holds using both Likert

\footnotetext{
${ }^{30}$ These results are available in the paper's GitHub repository.
} 
scores $(p$-value $<0.05)$ and verbal response data $(p$-value $<0.01)$. The Likert score data indicate that the differences are due to lower relevance for the balance sheet, whereas the verbal response data point to the income statement. ${ }^{31}$ The differences between means for different line items are all negative, and statistically significant for Financial instruments and Pension liabilities. While we are cautious not to over-interpret the weakly-powered line item-specific findings, these are consistent with the theoretical rationale for $\mathrm{H} 1$, as these line items are particularly affected by factors assumed to be beyond managerial control. The verbal response data produce a statistically significant difference only for Net income.

In contrast to the confirmatory results for $\mathrm{H} 1$, our findings in Table 6 , Panel $\mathrm{B}$, reveal no support for our prediction under $\mathrm{H} 2$ that the presence of earnings management incentives (the use of accounting data in managerial compensation) reduces investment professionals' assessments of the representational faithfulness of accounting information. None of the differences in Likert scores are statistically significant. Even Net income itself (i.e., the variable forming the basis for executive compensation in the accounting compensation treatment) has a difference of only 0.372 of a Likert score point, with an associated $p$-value of 0.44 . In summary, our line item-based test results offer support for $\mathrm{H} 1$, but not for $\mathrm{H} 2$.

Table 7, Panel A, presents the rationales provided to justify the relevance assessments, conditional on the information acquisition objective treatment. It is clear from the frequency table that the rationales match our predicted mechanisms. Investment professionals assigned a managerial performance evaluation objective are much more likely to discuss whether a certain line item is within managerial control, whereas those assigned a firm valuation objective focus

\footnotetext{
${ }^{31}$ The divergent findings for Likert score and verbal response data may be due to the nature of the interviews. As the interviews begin with the income statement, most coded verbal responses relate to the income statement. Later, when asked to evaluate balance sheet line items, subjects often refer back to arguments related to the income statement.
} 
their rationales on whether a certain line item is helpful for forecasting future firm activities or understanding the business model of the firm. These differences are statistically significant ( $p$ value $<0.01$ ), supporting the predicted mechanism underlying $\mathrm{H} 1$.

Table 7, Panel B, in turn, provides limited support for H2. It shows that managerial compensation issues are more often discussed when subjects receive case materials indicating accounting-based compensation arrangements for managers, but this difference is not statistically significant at conventional levels ( $p$-value $=0.12$ ). A similar observation holds for other managerial incentives, where the difference is marginally significant ( $p$-value $=0.08$ ). Subjects assigned an accounting-based compensation treatment talk significantly less about accounting and measurement complexity ( $p$-value $=0.03$ ). We contend this unexpected finding may be driven by these subjects devoting somewhat more time to managerial incentives issues combined. Overall, these findings indicate that the subjects treated with accounting-based compensation arrangements talk more about managerial incentives, which is consistent with them receiving the treatment, but not with this significantly affecting their assessments of representational faithfulness. ${ }^{32}$ However, we acknowledge that a weak treatment effect may be responsible for the failure to reject the null under $\mathrm{H} 2$.

Table 8 presents our final set of survey experiment test results by reporting whether our experimental treatments affect the relative share that our subjects allocate to financial accounting information from a hypothetical $€ 100,000$ budget, compared with their chosen three top alternative non-accounting sources. Financial reporting information constitutes only a portion of a firm's

\footnotetext{
${ }^{32} \mathrm{We}$ also conduct a supplementary analysis in which we use investment professionals' assessments of corporate governance quality as an independent variable. These assessments are obtained from the responses to the question "The firm in the case faces potentially serious corporate governance issues". The results of this (non-experimental) analysis (available in the paper's GitHub repository) suggest that positive assessments of corporate governance quality are associated with positive assessments of representational faithfulness.
} 
information environment (Ball and Shivakumar 2008; Beyer et al. 2010). One might expect this share to be higher under the firm valuation objective, given that investment professionals view accounting information as less relevant for the managerial performance evaluation objective. However, the budget allocated to a single information source depends not only on its usefulness, but also on the usefulness and availability of alternative information sources. While we do not assess the usefulness of alternative information sources directly, our subjects are likely to have different views about alternative sources depending on their objectives. Assuming that alternative information sources are more readily available and are more useful for the firm valuation objective, this may cause investment professionals to assign larger weights to financial accounting information when assigned a managerial performance evaluation objective, especially given that our case firm is privately owned.

The significantly positive coefficient for the main effect of the managerial performance evaluation treatment in Table 8, Panel B, indicates that investment professionals allocate a lower weight to financial accounting information when their assigned objective is firm valuation. ${ }^{33}$ This striking finding is consistent with the second expectation outlined above and indicates that, although investment professionals generally assess financial accounting information to be less suitable for evaluating managerial performance, they still use it more. The relatively low share assigned to firm valuation may reflect the wider variety of timelier and/or forward-looking sources available for that purpose (Ball and Shivakumar 2008). This hints at a potential competitive

\footnotetext{
${ }^{33}$ These inferences are confirmed by unreported multivariate tests in which we control for subjects' personal demographics and interviewer fixed effects. These results are available in the paper's GitHub repository.
} 
advantage of financial accounting information in managerial performance evaluation settings, even though it is not viewed as optimal for this objective. ${ }^{34}$

\section{FOLLOW-UP ONLINE EXPERIMENT}

\section{Research Design}

While our survey experiment provides important evidence for our research questions, it has two main shortcomings. First, its sample of 81 investment professionals (62 in the experimental design) provides limited statistical power. Second, it examines investment professionals' assessments rather than actions. To address these shortcomings, we design a large-scale follow-up online experiment that enables us to observe how a larger sample of investment professionals select a set of income statement line items to construct an adjusted earnings measure ${ }^{35}$ For this task, we give investment professionals basic information about a (different) fictional private European firm, including Sales and Cost of Sales numbers as the starting point for the task. We then ask subjects to construct their adjusted measure of earnings for the assessment of firm performance by selecting from a list of seven additional line items: Selling, general and administrative expenses; Depreciation and amortization; Fair value gains on marketable securities (mark to market); Fair value gains on unlisted equity instruments (mark to model); Gains on investment properties; Interest expense; and Taxation expense.

\footnotetext{
${ }^{34}$ As the positive effect of the managerial performance evaluation objective is predominantly driven by subjects who receive the case with managerial compensation based on non-accounting information, we also document a negative main effect for compensation being linked to financial accounting on the share of accounting information. This is consistent with investment professionals using financial accounting less when accounting information is used in compensation contracts, particularly when their information acquisition objective is to assess managerial performance. While we are cautious about offering a rationale for such an unpredicted effect, it is possible that investment professionals rely more on external information when evaluating managerial performance in these circumstances, as they prefer to balance the information used in compensation with outside information to assess its robustness.

${ }^{35}$ Further details of our follow-up online experiment, as well as the code and the response data, are available in the Online Appendix and in the paper's GitHub repository.
} 
Applying a $2 \times 2$ between-subjects design, we manipulate: (i) the corporate governance quality of the case firm (designated either as 'weak' or 'strong' relative to industry-peers); and (ii) the earnings management incentives (managerial compensation linked either to earnings or internal production data). We manipulate corporate governance quality to allay the concern that the null result of our survey experiment could be driven by strong corporate governance curtailing investment professionals' concerns over compensation-driven earnings management incentives. We deliberately choose line items that encompass varying degrees of managerial discretion. Specifically, since our objective is to understand whether subjects include/exclude line items that inflate earnings - and gain line items give rise to unambiguous expectations-we effectively manipulate the existence of income-increasing earnings management incentives. Our line items are also of similar magnitude to enable us to compare their inclusion probabilities in a meaningful way. Based on this, our interest lies in differences between: (i) the line items Fair value gains on unlisted equity instruments (mark to model) and Gains on investment properties (i.e., higher managerial discretion) and (ii) the line item Fair value gains on marketable securities (mark to market) (i.e., lower managerial discretion). Our expectation, which is based on $\mathrm{H} 2$, is that accounting-based managerial compensation makes it relatively less likely that our subjects include line items with higher levels of managerial discretion. In addition, we predict the same effect for subjects that receive the 'weak governance' treatment. Finally, we predict a negative interaction effect, meaning that the effect should be even more pronounced when corporate governance is weak and managerial compensation is based on accounting data.

\section{Sample and Descriptive Findings}

To administer the follow-up online experiment, we first obtain the email addresses of all individuals designated as 'Security Analyst,' 'Associate Analyst,' and 'Portfolio Manager' in the 
Eikon database, excluding portfolio managers whose secondary role descriptions indicate a passive approach to investing. We obtain 63,905 email addresses via this process. We email a link to the web-based task (sent late June and early July 2019). We receive delivery failure notifications from 7,507 recipients and, of the remaining $56,398,1,241$ responded to the email by accessing the task and 948 completed the task. Of these, 833 pass both manipulation checks and are thus included in our analysis. The size of our sample allays concerns about lack of power. Our response rate of approximately 2 percent is low, but broadly comparable with other large-scale surveys of professional investors (e.g., Drake et al. 2019). In our final sample, 596 subjects are characterized by Eikon as analysts and 237 as portfolio managers; 262 are based in North America, 377 in Europe, and 194 in the rest of the World.

Table 9, Panel A, reports the large variation in (unconditional) inclusion rates for all line items. Whereas virtually all subjects include Other selling, general and administrative expenses, and around three quarters include Depreciation and amortization, Interest expense, and Taxation expense, less than 14 percent include Fair value gains on marketable securities (mark to market) and only half of these (7 percent) include Fair value gains on unlisted equity instruments (mark to model). The difference between the gains variable with less managerial discretion (Fair value gains on marketable securities (mark to market)) and the other two gain variables is significant at conventional levels (Fair value gains on unlisted equity instruments (mark to model): pvalue $<0.01$; Gains on revaluation of investment property: $p$-value $<0.01$ ). These descriptive findings increase our confidence that the assessment-based findings of the first experiment match the task-based evidence from the follow-up online experiment. Investment professionals are more likely to use income statement line items that are less complex, fit the business model of the reporting firm, and are less prone to managerial discretion. 


\section{Test Results}

To examine the effects of the treatment on the usefulness of accounting information, our main tests examine managerial earnings incentives (i.e., linking managerial compensation to earnings), variation in corporate governance quality (i.e., weak or strong), and their interaction. To construct our dependent variable, we focus on the three line items Fair value gains on marketable securities (mark to market), Fair value gains on unlisted equity instruments (mark to model), and Gains on revaluation of investment property, because these three line items are similar in nature and magnitude. Our treatments are designed to make the subjects focus more on representational faithfulness when choosing line items for their adjusted earnings measure. This is intended to make them relatively more likely to include Fair value gains on marketable securities (mark to market) (low managerial discretion) and relatively less likely to include Fair value gains on unlisted equity instruments (mark to model) and Gains on revaluation of investment property (high managerial discretion). The results of our analysis assessing this effect are presented in Figures 4 and 5, as well as in Table 9, Panel B.

As Figure 4 illustrates, the effect of the earnings management incentives treatment on the likelihood that the gains line items are included is small and inconsistent. However, the pattern for the corporate governance treatment is clearly identifiable. Subjects presented with a weak corporate governance case are more likely to include Fair value gains on marketable securities (mark to market) and less likely to include Fair value gains on unlisted equity instruments (mark to model), as well as Gains on revaluation of investment property. Figure 5 contrasts our empirical predictions with our findings and presents our dependent variable, Delta Include, which we also use in our subject-level analysis, results of which are presented in Table 9, Panel B. Delta Include is the percentage point difference between: (i) the average of the inclusion probabilities for the line 
items Fair value gains on unlisted equity instruments (mark to model) and Gains on revaluation of investment property and (ii) the inclusion probability of the line item Fair value gains on marketable securities (mark to market). Because our subjects can either include (1) or not (0) a line item, Delta Include can vary between -1 and 1 with feasible values being $[-1,-0.5,0,0.5,1]$. We find a sizeable treatment effect of around four percentage points for the main effect of the corporate governance treatment, while we document no significant effect for the earnings management incentive treatment and also no identifiable interaction effect.

Table 9, Panel B, presents the results of our subject-level analysis in which we use Delta Include as dependent variable. Without including an interaction effect, we observe the significant 3.8 percentage point effect of the governance treatment that can also be observed from Figure 5 and no significant effect for the earnings management incentive treatment. When we include interaction effects, we find a marginally significant main effect for corporate governance and a positive (albeit insignificant) effect for the interaction, which runs counter to our expectations. Again, we find no significant effect for the earnings management incentive treatment.

We draw three conclusions from our follow-up online experiment. First, our task-based evidence is in line with our assessment-based evidence: Investment professionals are more likely to use financial accounting information if it fits the underlying business model of the reporting firm, is subject to little managerial discretion, and entails a lower degree of complexity. Second, high-quality governance makes investment professionals more tolerant of managerial discretion. Third, despite the substantially increased statistical power, we find no robust evidence that investment professionals consider accounting-based managerial compensation arrangements as significantly detrimental to the usefulness of accounting information. Again, however, we caution that this latter null result may be due to weakness in our treatment. 


\section{CONCLUSIONS}

We examine how investment professionals assess the usefulness of financial accounting information. We combine empirical evidence from a survey experiment and a large-scale followup online experiment and derive the following conclusions. Investment professionals assess the relevance of accounting information to be higher when it fits their information acquisition objective. When assigned a firm valuation objective, investment professionals prefer information that helps them in forecasting future cash flows and understanding the business. The latter is also relevant for investment professionals assigned a managerial performance evaluation objective. In addition, investment professionals under this condition use accounting information to disentangle managerial performance from factors beyond managerial control. Our experimental evidence indicates that investment professionals judge the current financial accounting environment to be more relevant for firm valuation than for evaluating managerial performance. This finding is in line with central tenets of agency theory (Gjesdal 1981; Paul 1992) and adds to the existing empirical evidence (Bushman et al. 2006; Banker et al. 2009; Drake et al. 2019), although it casts some doubt on the FASB and IASB concept of general purpose financial statements.

The assessed representational faithfulness of financial accounting information critically hinges on the complexity of the underlying firm fundamentals, as well as the extent of managerial judgment involved. Our follow-up online experiment provides no evidence that compensationinduced earnings management incentives alone trigger investment professionals to be more skeptical about line items involving high managerial judgment. At the same time, investment professionals are willing to accept a higher level of managerial judgment in accounting line items when the reporting firm has a high-quality corporate governance system. Collectively, our findings are consistent with investment professionals having a more holistic understanding of managerial 
incentives (as in Laux and Laux 2009) and with views that are critical of widespread beliefs that earnings management is pervasive (e.g., Ball 2013). Although subject to the caveat that our treatment may not be strong enough to detect a true underlying effect, this important finding contrasts with the long line of research that sees earnings management as a problematic consequence of tying compensation to accounting numbers (Watts and Zimmerman 1978; 1986; Healy 1985; Holthausen et al. 1995; Goldman and Slezak 2006; Crocker and Slemrod 2007; Dichev et al. 2013).

Regardless of its shortcomings, financial accounting information appears to remain a key input to investment professionals' decision making. The fact that this evaluation is more pronounced when investment professionals are assigned a managerial performance evaluation objective suggests a competitive advantage of financial accounting information for this objective. We believe this result is worthy of further investigation. Future research could also examine how to structure financial accounting information to cater to heterogeneous information acquisition objectives and whether the usefulness of accounting information varies with information acquisition objectives other than valuation or stewardship. 


\section{REFERENCES}

Alevy, J. E., M. S. Haigh, and J. A. List. 2007. Information cascades: Evidence from a field experiment with financial market professionals. Journal of Finance 62 (1): 151-180.

Anderson, S. B., J. L. Brown, L. Hodder, E. Patrick, and P. E. Hopkins. 2015. The effect of alternative accounting measurement bases on investors' assessments of managers' stewardship. Accounting, Organizations and Society 46: 100-114.

Armstrong, C. S., W. R. Guay, and J. P. Weber. 2010. The role of information of financial reporting in corporate governance and debt contracting. Journal of Accounting and Economics 50 (2): $179-234$.

Ball, R. 2001. Infrastructure Requirements for an Economically Efficient System of Public Financial Reporting and Disclosure. Brookings-Wharton Papers on Financial Services.

Ball, R. 2013. Accounting informs investors and earnings management is rife: Two questionable beliefs. Accounting Horizons 27 (4): 847-853.

Ball, R., and L. Shivakumar. 2008. How much new information is there in earnings? Journal of Accounting Research 46 (5): 975-1016.

Banker, R.D., R. Huang, and R. Natarajan. 2009. Incentive contracting and value relevance of earnings and cash flows. Journal of Accounting Research 47 (3): 647-678.

Basu, S., T. X. Duong, S. Markov, and E. J. Tan. 2013. How important are earnings announcements as an information source? European Accounting Review 22 (2): 221-256.

Bergstresser, D., and T. Philippon. 2006. CEO incentives and earnings management. Journal of Financial Economics 80 (3): 511-529.

Beyer, A., D. A Cohen, T. Z. Lys, and B. R. Walther. 2010. The financial reporting environment: Review of the recent literature. Journal of Accounting and Economics 50 (2): 296-343.

Black, D. E., T.E. Christensen, J.T. Ciesielski, and B.C. Whipple. 2018. Non-GAAP reporting: Evidence from academia and current practice. Journal of Business Finance \& Accounting 45 (3-4): 259-294.

Bloomfield, R., M. W. Nelson, and E. Soltes. 2016. Gathering data for archival, field, survey, and experimental accounting research. Journal of Accounting Research 54 (2): 341-395.

Bradshaw, M., and R. Sloan. 2002. GAAP versus The Street: An empirical assessment of two alternative definitions of earnings. Journal of Accounting Research 40 (1): 41-66.

Bradshaw, M. T., T.E. Christensen, K.H. Gee, and B.C. Whipple. 2018. Analysts' GAAP earnings forecasts and their implications for accounting research. Journal of Accounting and Economics 66 (1): 46-66.

Brown, L. D., A. C. Call, M. B. Clement, and N. Y. Sharp. 2015. Inside the "Black Box" of sellside financial analysts. Journal of Accounting Research 53 (1): 1-47.

Brown, L. D., A. C. Call, M. B. Clement, and N. Y. Sharp. 2016. The activities of buy-side analysts and the determinants of their stock recommendations. Journal of Accounting and Economics 62 (1): 139-156.

Bushman, R., E. Engel, and A. Smith. 2006. An analysis of the relation between the stewardship and valuation roles of earnings. Journal of Accounting Research 44 (1): 53-83.

Christensen-Szalanski, J. J. J., and L. R. Beach. 1984. The citation bias: Fad and fashion in the judgment and decision literature. American Psychologist 39 (1): 75-78.

Christensen, P. O., G. A. Feltham, and F. Sabac. 2005. A contracting perspective on earnings quality. Journal of Accounting and Economics 39 (2): 265-294. 
Clor-Proell, S., L. Koonce, and B. White. 2016. How do experienced users evaluate hybrid financial instruments? Journal of Accounting Research 54 (5): 1267-1296.

Crocker, K. T., and J. Slemrod. 2007. The economics of earnings manipulation and managerial compensation. The Rand Journal of Economics 38 (3): 698-713.

Dechow, P., W. Ge., and C. Schrand. 2010. Understanding earnings quality: A review of the proxies, their determinants and their consequences. Journal of Accounting and Economics 50 (2): 344-401.

Dichev, I. D., J. R. Graham, C. R. Harvey, and S. Rajgopal. 2013. Earnings quality: Evidence from the field. Journal of Accounting and Economics 56 (1): 1-33.

Dichev, I. D., J. R. Graham, C.R. Harvey, and S. Rajgopal. 2016. The misrepresentation of earnings. Financial Analysts Journal 72 (1): 22-35.

Doyle, J., R. Lundholm, and M. Soliman. 2003. The predictive value of expenses excluded from pro forma earnings. Review of Accounting Studies 8 (2-3): 145-174.

Drake, M. S., J. Hales, and L. Rees. 2019. Disclosure overload? A professional-user perspective on the usefulness of general purpose financial statements. Contemporary Accounting Research 36 (4): 1935-1965.

Drake, M. S., D.T. Roulstone, and J. Thornock. 2016. The usefulness of historical accounting reports. Journal of Accounting and Economics 61 (2-3): 448-464.

Druckman, J. N., D. P. Green, J. H. Kuklinski, and A. Lupia. 2006. The growth and development of experimental research in political science. American Political Science Review 100(4): 627635.

Drymiotes, G., and T. Hemmer. 2013. On the stewardship and valuation implications of accrual accounting systems. Journal of Accounting Research 51 (2): 281-334.

Elliott, W. B., F. D. Hodge, and K. E. Jackson. 2008. The association between nonprofessional investors' information choices and their portfolio returns: The importance of investing experience. Contemporary Accounting Research 25 (2): 473-498.

Emett, S. A., and M. W. Nelson. 2015. Discussion of "The effect of alternative accounting measurement bases on investors' assessments of managers' stewardship". Accounting, Organizations and Society 46: 115-118.

Erb, C., and C. Pelger. 2015. "Twisting words"? A study of the construction and reconstruction of reliability in financial reporting standard-setting. Accounting, Organizations and Society 40: $13-40$.

Ewert R., and A. Wagenhofer. 2005 Economic effects of tightening accounting standards to restrict earnings management. The Accounting Review 80 (4): 1101-1124.

Financial Accounting Standards Board. 2010. Statement of Financial Accounting Concepts No. 8. Conceptual Framework for Financial Reporting. Chapter 3, Qualitative Characteristics of Useful Financial Information. Norwalk, CT.

Fischer, P.E., and Verrecchia, R.E. 2000. Reporting bias. The Accounting Review 75(2): 229-245.

Gassen, J., and K. Schwelder. 2010. The decision usefulness of financial accounting measurement concepts: Evidence from an online survey of professional investors and their advisors. European Accounting Review 19 (3): 495-509.

Georgiou, O. 2018. The worth of fair value accounting: Dissonance between users and standard setters. Contemporary Accounting Research 35(3): 1297-1331.

Gjesdal, F. 1981. Accounting for stewardship. Journal of Accounting Research 19 (1): 208-231.

Goldman, E., and S. L. Slezak. 2006. An equilibrium model of incentive contracts in the presence of information manipulation. Journal of Financial Economics 80 (3): 603-626. 
Graham, J. R., C. R. Harvey, and S. Rajgopal. 2005. The economic implications of corporate financial reporting. Journal of Accounting and Economics 40 (1-3): 3-73.

$\mathrm{Gu}, \mathrm{Z}$., and T. Chen. 2004. Analysts' treatment of nonrecurring items in street earnings. Journal of Accounting and Economics 38 (1-3): 129-170.

Guttman, I. 2013. Discussion of "On the stewardship and valuation implications of accrual accounting systems". Journal of Accounting Research 51 (2): 335-347.

Harris, M., and A. Raviv. 1978. Some results on incentive contracts with applications to education and employment, health insurance, and law enforcement. American Economic Review 68 (1): 20-30.

Healy, P. M. 1985. The effect of bonus schemes on accounting decisions. Journal of Accounting and Economics 7 (1): 85-107.

Healy, P. M., and J. M. Wahlen. 1999. A review of the earnings management literature and its implications for standard setting. Accounting Horizons 13 (4): 365-383.

Hoitash, R., and U. Hoitash. 2018. Measuring accounting reporting complexity with XBRL. The Accounting Review 93 (1): 259-287.

Holmström, B. 1979. Moral hazard and observability. Bell Journal of Economics 10 (1): 74-91.

Holthausen, R., D. Larcker, and R. Sloan. 1995. Annual bonus schemes and the manipulation of earnings. Journal of Accounting and Economics 19 (1): 29-74.

International Accounting Standards Board. 2018. Conceptual Framework for Financial Reporting. London: IFRS Foundation Publications Department.

Kadous, K., L. Koonce, and J. M. Thayer. 2012. Do financial statement users judge relevance based on properties of reliability? The Accounting Review 87 (4): 1335-1356.

Klein, A. 2002. Audit committee, board of director characteristics, and earnings management. Journal of Accounting and Economics 33 (3): 375-400.

Kothari, S.P., K. Ramanna, and D. J. Skinner. 2010. Implications for GAAP from an analysis of positive research in accounting. Journal of Accounting and Economics 50 (2-3): 246-286.

Kraft, P. 2014. Rating agency adjustments to GAAP financial statements and their effect on ratings and credit spreads. Available at https://ssrn.com/abstract=1266381.

Kuziemko, I., M. I. Norton, E. Saez, and S. Stantcheva. 2015. How elastic are preferences for redistribution? Evidence from randomized survey experiments. American Economic Review 105 (4): 1478-1508.

Lambert, R. A. 2001. Contracting theory and accounting. Journal of Accounting and Economics 32 (1): 3-87.

Laux. C., and V. Laux. 2009. Board committees, CEO compensation, and earnings management. The Accounting Review 84 (3): 869-891.

List, J.A. 2011. Why economists should conduct field experiments and 14 tips for pulling one off. Journal of Economic Perspectives 25 (3): 3-15.

List, J. A., M. S. Haigh, and M. Nerlove. 2005. A simple test of expected utility theory using professional traders. Proceedings of the National Academy of Sciences of the United States of America 102 (3): 945-948.

Murphy, T., V. O’Connell, and C. Ó hÓgartaigh. 2013. Discourses surrounding the evolution of the IASB/FASB Conceptual Framework: What they reveal about the "living law" of accounting. Accounting, Organizations and Society 38 (1): 72-91.

O'Connell, V. 2007. Reflections on stewardship reporting. Accounting Horizons 21 (2): 215-227.

Paul, J. M. 1992. On the efficiency of stock-based compensation. Review of Financial Studies 5 (3): 471-502. 
Peasnell, K. V., P. F. Pope, and S. Young. 2005. Board monitoring and earnings management: Do outside directors influence abnormal accruals? Journal of Business Finance \& Accounting 32 (7/8): 1311-1346.

Pelger, C. 2016. Practices of standard-setting - An analysis of the IASB's and FASB's process of identifying the objective of financial reporting. Accounting, Organizations and Society 50: 5173.

Reimsbach, D., R. Hahn, and A. Gürtürk. 2018. Integrated reporting and assurance of sustainability information: An experimental study on professional investors' information processing. European Accounting Review 27 (3): 559-581.

Sloan, R. G. 1993. Accounting earnings and top executive compensation. Journal of Accounting and Economics 16 (1): 55-100.

Stein, J. 1989. Efficient capital markets, inefficient firms: A model of myopic corporate behavior. The Quarterly Journal of Economics 104 (4): 655-669.

Wallander, L. 2009. 25 years of factorial surveys in sociology. Social Science Research 38 (3): 505-520.

Watts, R. L., and J. L. Zimmerman. 1986. Positive Accounting Theory. Englewood Cliffs, N.J.: Prentice-Hall.

Watts, R. L., and J. L. Zimmerman. 1978. Towards a positive theory of the determination of accounting standards. The Accounting Review 53 (1): 112-134.

Zeff, S.A. 2013. The objectives of financial reporting: A historical survey and analysis. Accounting and Business Research 43 (4): 262-327. 


\section{Exhibits 1 and 2}

\section{EXHIBIT 1: Financial Information}

\begin{tabular}{l|r}
\hline Summary Balance Sheet (€ m) \\
\hline Cash & 208 \\
\hline Receivables & 212 \\
\hline Inventory & 105 \\
\hline Financial investments & 634 \\
\hline Plant and equipment & 416 \\
\hline Goodwill & 443 \\
\hline Other intangible assets & 432 \\
\hline Total assets & $\mathbf{2 , 4 5 0}$ \\
\hline Trade payables & 216 \\
\hline Pension liabilities & 435 \\
\hline Long term debt & 628 \\
\hline Equity & 1,171 \\
\hline Total liabilities and equity & $\mathbf{2 , 4 5 0}$ \\
\hline
\end{tabular}

\begin{tabular}{l|r}
\hline Annual Income Statement (€ m) \\
\hline Revenue & 2,185 \\
\hline Cost of sales & $(1,382)$ \\
\hline Other expenses & $(416)$ \\
\hline Investment income & 148 \\
\hline EBITDA & 535 \\
\hline Depreciation and amortization & $(114)$ \\
\hline Goodwill impairment & $(58)$ \\
\hline EBIT & 363 \\
\hline Interest expenses & $(80)$ \\
\hline Taxes & $(123)$ \\
\hline Net income & $\underline{\mathbf{1 6 0}}$ \\
\hline
\end{tabular}

\section{Accounting policy information}

The financial statements are prepared using IFRS. The firm uses a historical cost basis except that financial instruments are measured at fair value and certain other assets and liabilities are included on an alternative basis - most significantly, pension liabilities.

Summary of selected accounting policies

Plant and equipment and other intangible assets are measured at cost. The value of goodwill is tested for impairment on an annual basis. Financial investments are measured at fair value, with changes in fair value directly reflected in net income. Pension liabilities are the net of the present value of defined benefit plan obligations and external plan assets.

Key areas of judgment and estimation uncertainty

The key areas of estimation uncertainty and of judgment required in applying the firm's accounting policies are:

- The firm holds a number of minority investments in firms that are not listed on public equity markets. These investments are measured at fair value, requiring the use of managerial estimates.

- The firm has significant intangible assets. Judgment is required to decide whether intangible assets should be recognized and in determining goodwill and intangible asset impairments.

- The accounting valuation of the pension liability is based on assumptions determined with independent actuarial advice and is assessed annually.

\section{EXHIBIT 2: Auditing and corporate governance information}

The firm is audited by a leading audit firm. The corporate governance is of a high standard and comfortably passes a quality level that would be required from a publicly-listed firm of the same size. In fact, the CGFA Institute, a wellreputed independent group that evaluates corporate governance and makes this information available to current and future investors, has rated the firm as an industry leader in corporate governance quality, assessing the quality of the firm corporate governance as seen below.

Independent assessment of the firm's corporate governance quality

\begin{tabular}{|c|c|c|c|c|c|c|c|c|}
\hline 1 & 2 & 3 & 4 & 5 & 6 & 7 & 8 & 9 \\
$1=$ Lowest standard \\
1=
\end{tabular}


Figure 1: Treatment Conditions of Survey Experiment

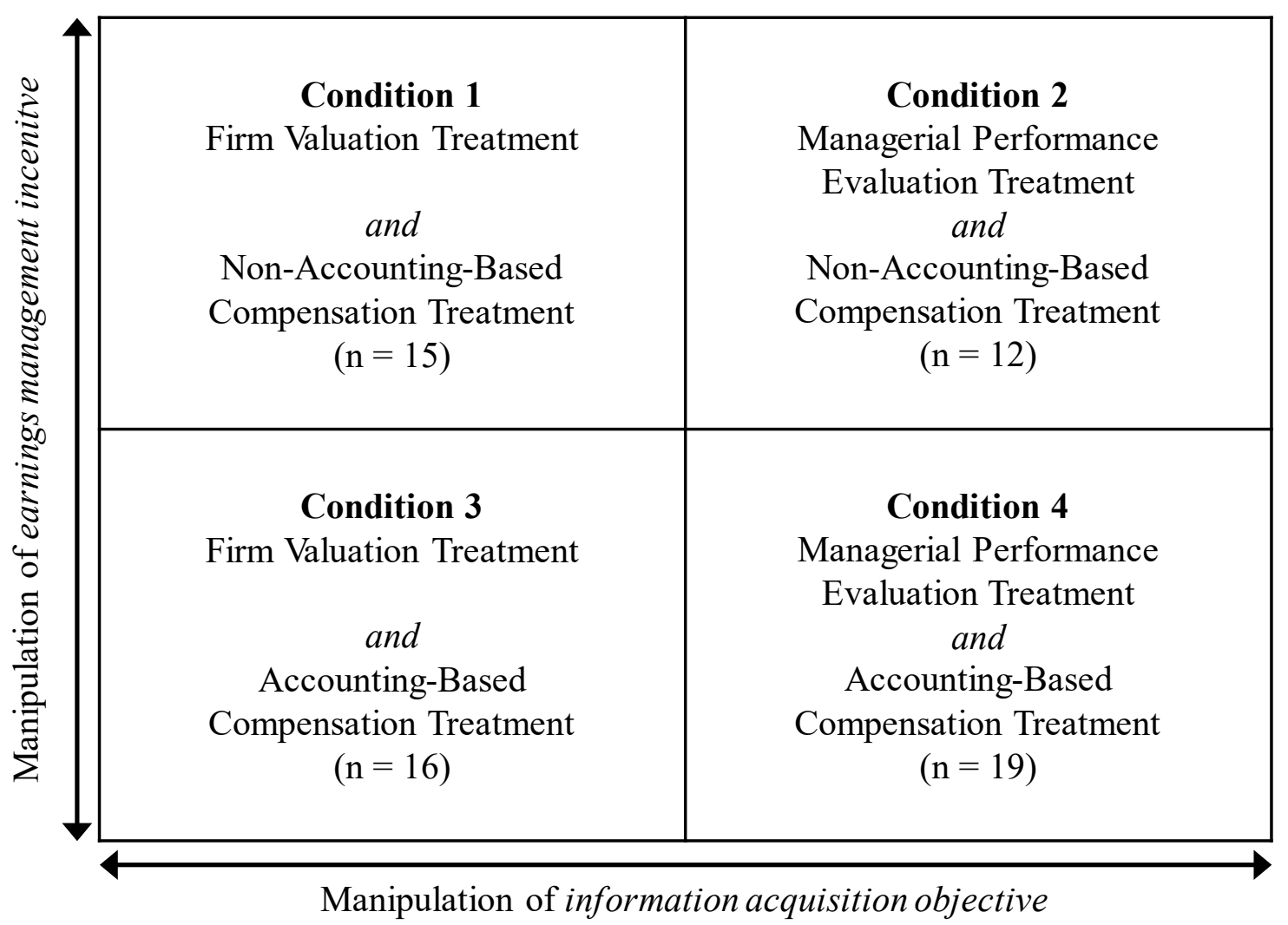

This figure presents the design of our survey experiment. We manipulate the information acquisition objective and the earnings management incentives, generating four different $(2 \times 2)$ conditions. These conditions are administered to our subjects in a between-subject design. Each subject in our survey experiment receives only one condition and is not aware that multiple conditions exist. The reported cell sizes refer to 62 total observations of the Experimental Sample. 
Figure 2: Predictions and Empirical Findings of Survey Experiment
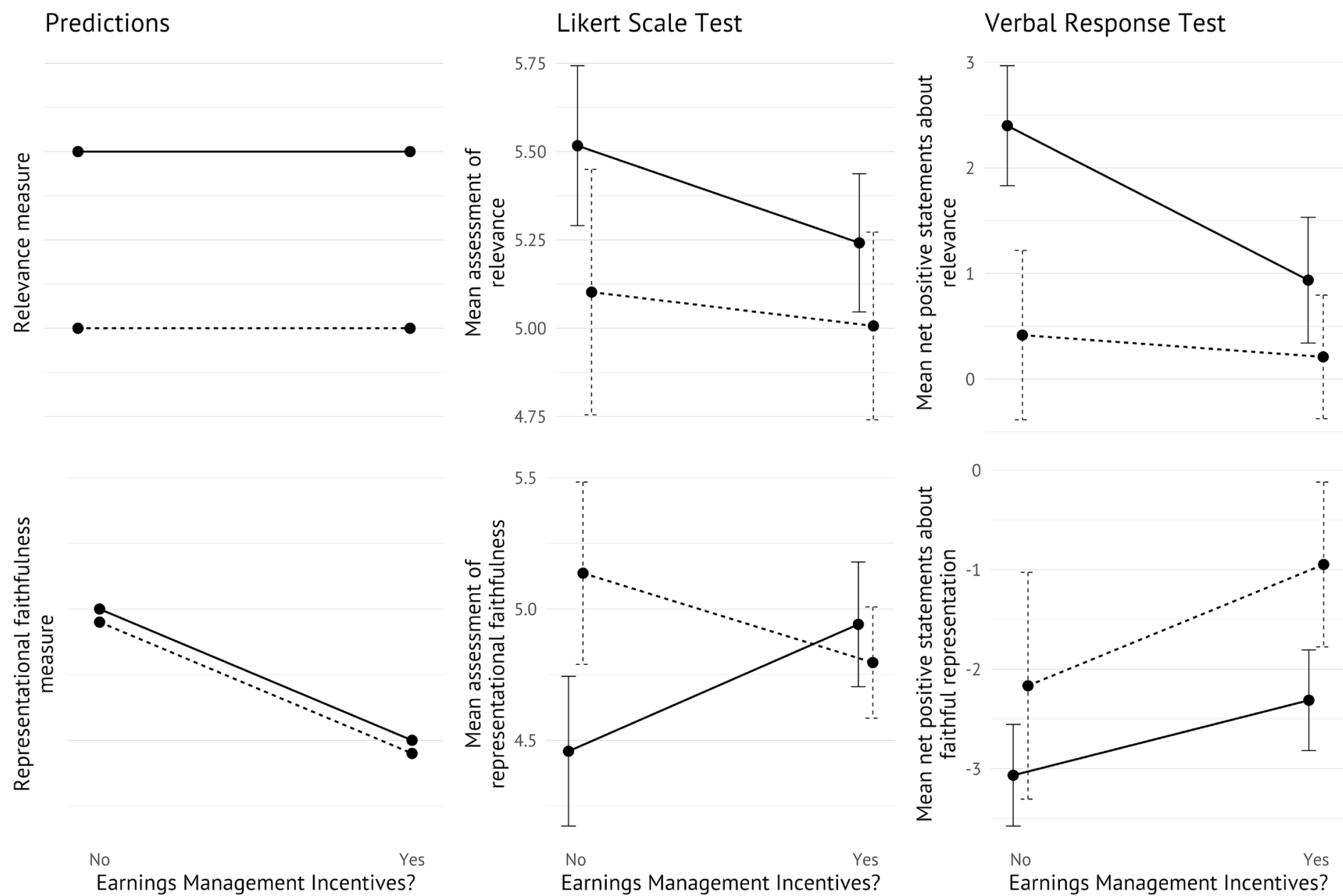

No
Earnings Management Incentives?

Earnings Management Incentives?

Earnings Management Incentives?

This figure reports the predicted effects of our two manipulations (i.e., information acquisition objective and earnings management incentives) on the assessed usefulness of financial accounting information (left column), as well as the univariate mean effects for a sample of 62 investment professionals based on Likert score data (middle column) and verbal response data (right column). The solid line indicates the valuation treatment conditions and the dashed line indicates the managerial performance evaluation conditions. The bars capture the standard errors of the respective treatment condition. 


\section{Figure 3: Screenshot of Follow-Up Online Experiment}

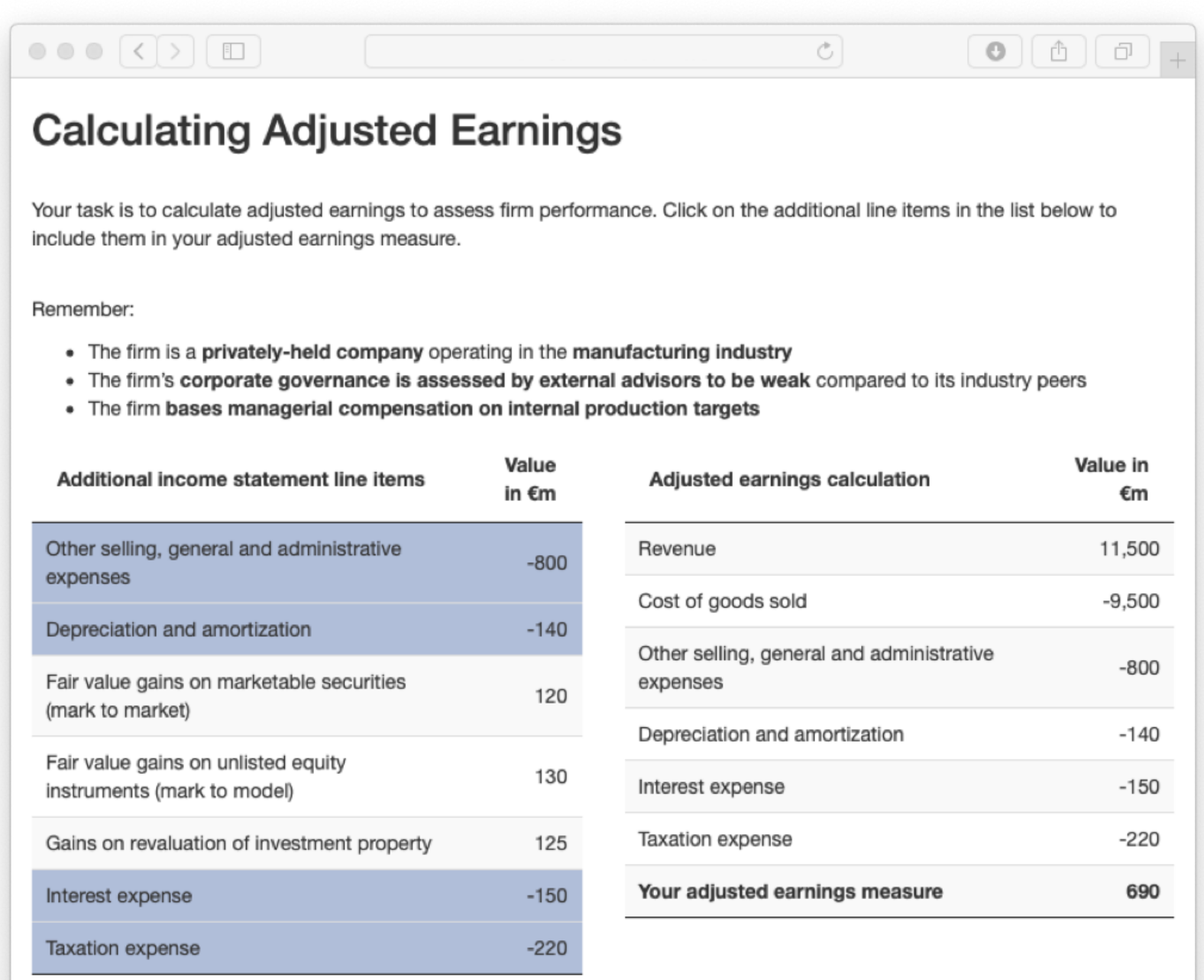

When you feel that your adjusted earnings measure is suitable to assess firm performance press the submit button below.

\section{Submit}

This screenshot captures the main experimental screen of our follow-up online experiment. The screenshot portrays the actions of a fictional subject who selects the highlighted line items to include in her/his adjusted earnings measure. Further details of the follow-up online experiment are presented in the Online Appendix and in the paper's GitHub repository. 


\section{Figure 4: Follow-Up Online Experiment Gain Line Item Findings}

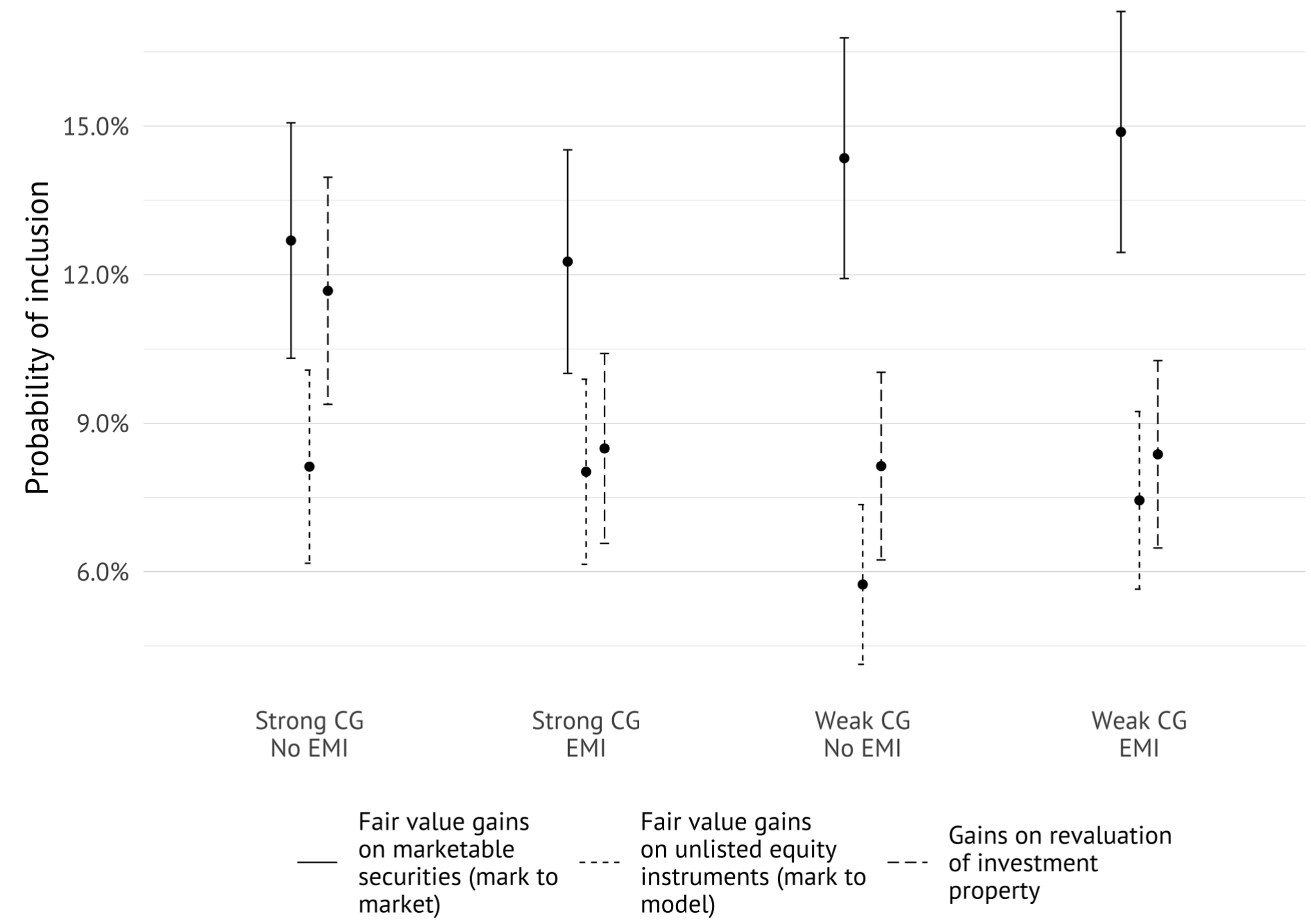

This figure reports the effects of our two manipulations (i.e., strength of corporate governance system and earnings management incentives) on the inclusion probability of the gain line items. The bars capture the standard errors of the inclusion probability of the given line item for the respective treatment condition. 


\section{Figure 5: Follow-Up Online Experiment Predictions and Empirical Findings}

\section{Predictions}

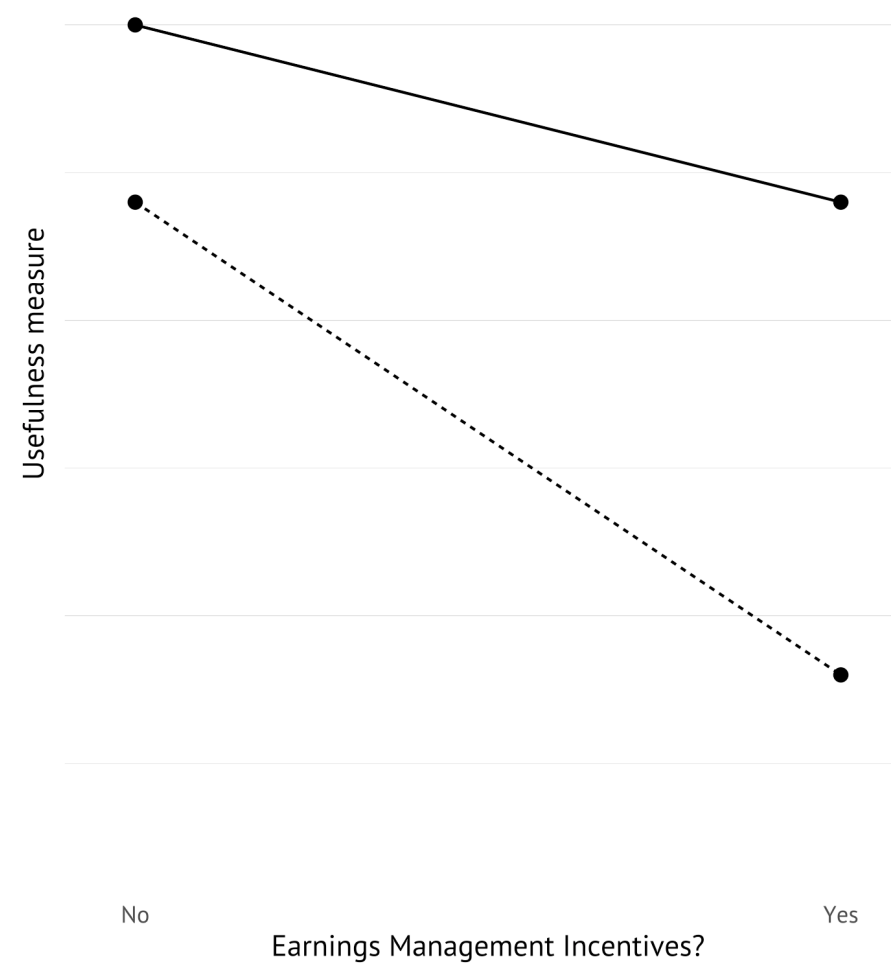

Findings

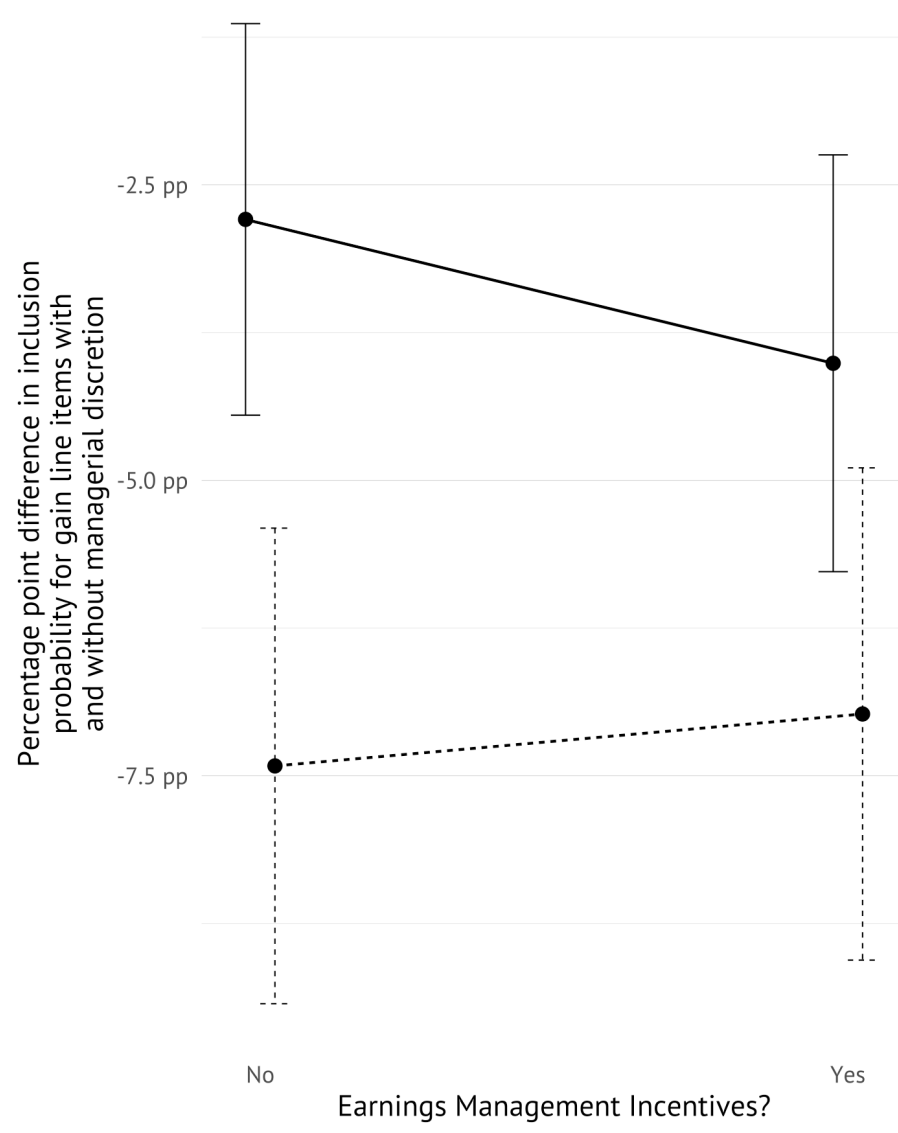

This figure reports the predicted effects of our two manipulations (i.e., strength of corporate governance system and earnings management incentives) on the usefulness of financial accounting information (left column), as well as the univariate mean effects for a sample of 833 investment professionals based on the differential inclusion probability for gain line items with and without managerial discretion (right column). The solid line indicates the high-quality corporate governance treatment conditions and the dashed line indicates the low-quality corporate governance conditions. The bars capture the standard errors of the respective treatment condition. 


\section{Table 1: Sample Composition and Personal Demographics}

Panel A: Sample Composition.

\begin{tabular}{lcc}
\hline \hline \multirow{2}{*}{ Sample Construction } & \multicolumn{2}{c}{ Obs. } \\
\cline { 2 - 3 } Full Sample & Interviews & Verbal Responses \\
\hline - Interviews from the experimental pilot phase & 81 & 696 \\
- Interviews with failed manipulation checks & $(5)$ & $(61)$ \\
\hline Experimental Sample & $(14)$ & $(98)$ \\
\hline \hline
\end{tabular}

Panel B: Full Sample Personal Demographics - Country of Work

\begin{tabular}{lrr}
\hline \hline Country of Work & Obs. & $\%$ \\
\hline Austria & 2 & 2.5 \\
Belgium & 5 & 6.2 \\
Canada & 4 & 4.9 \\
Croatia & 2 & 2.5 \\
Denmark & 7 & 8.6 \\
France & 3 & 3.7 \\
Germany & 6 & 7.4 \\
Italy & 3 & 3.7 \\
Norway & 3 & 2.5 \\
Portugal & 2 & 1.2 \\
Serbia & 1 & 1.2 \\
Spain & 1 & 3.7 \\
Sweden & 3 & 3.7 \\
Switzerland & 3 & 7.4 \\
United Kingdom & 3 & 34.6 \\
United States & 6.2 \\
\hline Total & 28 & 100.0 \\
\hline \hline
\end{tabular}

Panel C: Full Sample Personal Demographics - Age Group

\begin{tabular}{lrr}
\hline \hline Age Group & Obs. & $\%$ \\
\hline $20-25$ & 1 & 1.2 \\
$26-30$ & 5 & 6.2 \\
$31-35$ & 7 & 8.6 \\
$36-40$ & 11 & 13.6 \\
$41-45$ & 20 & 24.7 \\
$46-50$ & 16 & 19.8 \\
$51-55$ & 8 & 9.9 \\
$56-60$ & 8 & 9.9 \\
$>60$ & 5 & 6.2 \\
\hline Total & 5 & 100.0 \\
\hline \hline
\end{tabular}

Panel A presents the different samples used in our survey experiment. The Full Sample comprises 81 interviews for which 696 verbal responses are coded. The Experimental Sample is based on a subsample of interviews from the Full Sample for which: (i) interviews from the experimental pilot phase are excluded; and (ii) all subjects pass the manipulation checks. Panels B and C report key demographic information about the interviewed investment professionals. Descriptive statistics are based on the Full Sample of 81 interviews. 


\section{Table 2: Full Sample Occupational Demographics}

Panel A: Nature of Occupation

\begin{tabular}{lrr}
\hline \hline Occupation & Obs. & $\%$ \\
\hline Fund Manager & 44 & 54.3 \\
Analyst (sell-side) & 22 & 27.2 \\
Analyst (buy-side) & 12 & 14.8 \\
Other & 3 & 3.7 \\
\hline Total & 81 & 100.0 \\
\hline \hline
\end{tabular}

Panel B: Investment Characteristics

\begin{tabular}{lrr}
\hline \hline Investment Characteristic & Obs. & $\%$ \\
\hline By asset class: & 69 & 85.2 \\
$\quad$ Equity only & 9 & 11.1 \\
Debt only & 3 & 3.7 \\
$\quad$ Equity and debt & & \\
\hline By listing type: & 58 & 71.6 \\
$\quad$ Public firms only & 17 & 21.0 \\
Public and private firms & 6 & 7.4 \\
$\quad$ Private firms only & & \\
\hline By industry focus: & 36 & 44.4 \\
$\quad$ None & 34 & 42.0 \\
Non-financial & 11 & 13.6 \\
Financial & & \\
\hline By geographic focus: & 46 & 56.8 \\
$\quad$ Europe & 27 & 33.3 \\
World & 6 & 7.4 \\
North America & 2 & 2.5 \\
$\quad$ Asia & 81 & 100.0 \\
\hline Total & & \\
\hline \hline
\end{tabular}

Panel C: Investment Experience

\begin{tabular}{lrrrrrr}
\hline \hline Variable & Obs. & Mean & Std. Dev. & P25 & Median & P75 \\
\hline Number of stocks monitored per year & 77 & 61.1 & 70.0 & 18.0 & 35.0 & 85.0 \\
Years of experience overall & 81 & 20.1 & 8.6 & 15.0 & 20.0 & 25.0 \\
Years of experience in current position & 78 & 8.9 & 7.6 & 3.0 & 7.5 & 13.0 \\
\hline \hline
\end{tabular}

Panel D: Characteristics of Funds under Management

\begin{tabular}{lrrrrrr}
\hline \hline Variable & Obs. & Mean & Std. Dev. & P25 & Median & P75 \\
\hline Value of funds under management & 38 & $1,562.4$ & $2,864.6$ & 100.0 & 436.6 & $1,700.0$ \\
(USD Mil.) & 38 & 82.3 & 138.4 & 30.0 & 50.0 & 88.0 \\
Number of stocks held & 38 & 3.7 & 4.7 & 1.8 & 3.5 & 4.0 \\
Average holding period (Years) & & &
\end{tabular}

This table reports information about the investment background of the interviewed investment professionals. Descriptive statistics are based on the Full Sample of 81 investment professionals. Panel A presents the sample breakdown by nature of occupation. Panel B presents descriptive information about investment characteristics. Panel $\mathrm{C}$ presents information on investment experience, and Panel D presents information about the characteristics of the funds under management. 
Table 3: Assessed Usefulness of Financial Accounting Information - Descriptive Evidence

Panel A: Relevance

\begin{tabular}{|c|c|c|c|c|c|c|c|c|c|c|c|c|c|c|}
\hline & \multicolumn{9}{|c|}{ Likert Score Analysis } & \multicolumn{5}{|c|}{ Verbal Response Analysis } \\
\hline & \multicolumn{9}{|c|}{$\begin{array}{c}\text { Full Sample } \\
\text { (81 Interviews) }\end{array}$} & \multicolumn{5}{|c|}{$\begin{array}{c}\text { Full Sample } \\
\text { (81 Interviews } \mid 256 \text { Verbal Responses) }\end{array}$} \\
\hline & \multicolumn{9}{|c|}{ Likert Scores (1: Very Low - 7: Very High) } & \multicolumn{5}{|c|}{ Tone (Negative - Neutral - Positive) } \\
\hline & Mean & Std. Dev. & 1 & 2 & 3 & 4 & 5 & 6 & 7 & Obs. & Negative & Neutral & Positive & $\%$ Positive \\
\hline Financial statements (all) & 5.097 & 1.047 & 33 & 47 & 45 & 84 & 117 & 134 & 188 & 256 & 92 & 16 & 148 & $57.8 \%$ \\
\hline \multicolumn{15}{|l|}{ By financial statement component: } \\
\hline Income statement & 5.831 & 0.879 & 4 & 5 & 9 & 26 & 31 & 59 & 109 & 110 & 29 & 5 & 76 & $69.1 \%$ \\
\hline Balance sheet & 4.657 & 1.347 & 29 & 42 & 36 & 58 & 86 & 75 & 79 & 132 & 59 & 8 & 65 & $49.2 \%$ \\
\hline \multicolumn{15}{|l|}{ By line item: } \\
\hline$\overline{\text { Revenue }}$ & 6.383 & 1.168 & 2 & 0 & 0 & 3 & 6 & 17 & 53 & 31 & 2 & 1 & 28 & $90.3 \%$ \\
\hline EBITDA & 5.988 & 1.309 & 1 & 1 & 3 & 5 & 11 & 22 & 38 & 34 & 7 & 1 & 26 & $76.5 \%$ \\
\hline Net income & 5.123 & 1.520 & 1 & 4 & 6 & 18 & 14 & 20 & 18 & 39 & 20 & 2 & 17 & $43.6 \%$ \\
\hline Property, plant and equipment & 4.210 & 1.730 & 6 & 7 & 15 & 19 & 15 & 8 & 11 & 23 & 15 & 0 & 8 & $34.8 \%$ \\
\hline Financial instruments & 5.173 & 1.679 & 3 & 5 & 5 & 11 & 16 & 20 & 21 & 27 & 7 & 2 & 18 & $66.7 \%$ \\
\hline Intangible assets (excl. goodwill) & 4.395 & 1.947 & 8 & 10 & 9 & 9 & 20 & 10 & 15 & 21 & 10 & 2 & 9 & $42.9 \%$ \\
\hline Goodwill & 4.222 & 2.086 & 11 & 14 & 4 & 10 & 15 & 13 & 14 & 39 & 16 & 2 & 21 & $53.8 \%$ \\
\hline Pension liabilities & 5.284 & 1.502 & 1 & 6 & 3 & 9 & 20 & 24 & 18 & 18 & 7 & 2 & 9 & $50.0 \%$ \\
\hline
\end{tabular}


Table 3 (continued)

Panel B: Representational Faithfulness

\begin{tabular}{|c|c|c|c|c|c|c|c|c|c|c|c|c|c|c|}
\hline & \multicolumn{9}{|c|}{ Likert Score Analysis } & \multicolumn{5}{|c|}{ Verbal Response Analysis } \\
\hline & \multicolumn{9}{|c|}{$\begin{array}{c}\text { Full Sample } \\
\text { (81 Interviews) }\end{array}$} & \multicolumn{5}{|c|}{$\begin{array}{l}\text { Full Sample } \\
\text { (81 interviews } \mid 440 \text { Verbal Responses) }\end{array}$} \\
\hline & \multicolumn{9}{|c|}{ Likert Scores (1: Very Low - 7: Very High) } & \multicolumn{5}{|c|}{ Tone (Negative - Neutral - Positive) } \\
\hline & Mean & Std. Dev. & 1 & 2 & 3 & 4 & 5 & 6 & 7 & Obs. & Negative & Neutral & Positive & $\%$ Positive \\
\hline Financial statements (all) & 4.689 & 1.046 & 9 & 26 & 28 & 39 & 48 & 53 & 40 & 440 & 297 & 20 & 123 & $28.0 \%$ \\
\hline \multicolumn{15}{|l|}{ By financial statement component: } \\
\hline Income statement & 5.142 & 1.137 & 7 & 15 & 23 & 26 & 49 & 69 & 53 & 127 & 97 & 2 & 28 & $22.0 \%$ \\
\hline Balance sheet & 4.418 & 1.205 & 7 & 17 & 26 & 32 & 52 & 63 & 46 & 217 & 158 & 11 & 48 & $22.1 \%$ \\
\hline \multicolumn{15}{|l|}{ By line item: } \\
\hline Revenue & 5.963 & 1.096 & 0 & 1 & 2 & 6 & 9 & 34 & 28 & 34 & 15 & 1 & 18 & $52.9 \%$ \\
\hline EBITDA & 5.012 & 1.624 & 3 & 4 & 9 & 9 & 19 & 22 & 15 & 40 & 33 & 1 & 6 & $15.0 \%$ \\
\hline Net income & 4.407 & 1.723 & 4 & 10 & 12 & 11 & 21 & 13 & 10 & 40 & 40 & 0 & 0 & $0.0 \%$ \\
\hline Property, plant and equipment & 5.481 & 1.379 & 0 & 3 & 5 & 12 & 12 & 28 & 21 & 19 & 5 & 1 & 13 & $68.4 \%$ \\
\hline Financial instruments & 4.173 & 1.766 & 5 & 13 & 11 & 16 & 15 & 12 & 9 & 67 & 59 & 2 & 6 & $9.0 \%$ \\
\hline Intangible assets (excl. goodwill) & 3.864 & 1.579 & 4 & 14 & 19 & 13 & 18 & 9 & 4 & 40 & 34 & 3 & 3 & $7.5 \%$ \\
\hline Goodwill & 3.765 & 1.720 & 12 & 8 & 14 & 16 & 19 & 8 & 4 & 43 & 38 & 2 & 3 & $7.0 \%$ \\
\hline Pension liabilities & 4.775 & 1.583 & 4 & 5 & 6 & 12 & 26 & 17 & 10 & 45 & 19 & 3 & 23 & $51.1 \%$ \\
\hline
\end{tabular}

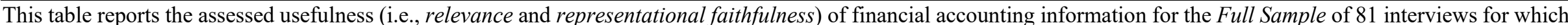

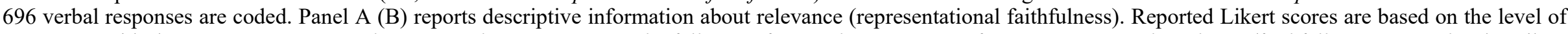

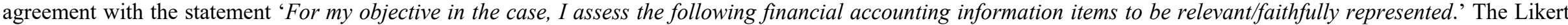

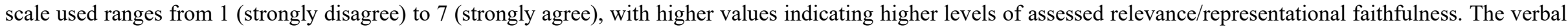

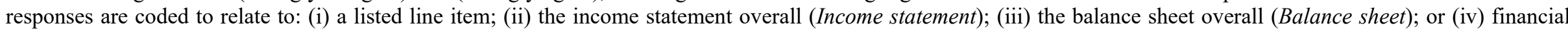

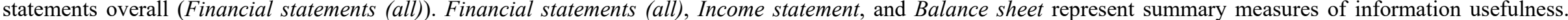

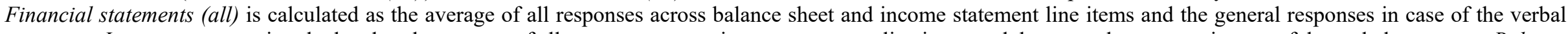

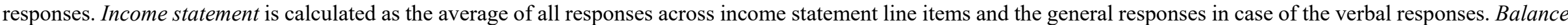

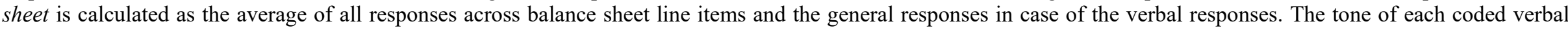

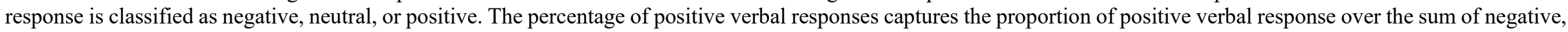
neutral, and positive verbal responses. 
Table 4: Rationales Underlying Usefulness Assessments

Full Sample

(256 Verbal Responses)

\begin{tabular}{lcc} 
Rationale: & Verbal Responses & \% Positive Responses \\
\cline { 2 - 3 } Relevant for forecasting & 83 & $62.7 \%$ \\
Relates to managerial impact and/or control & 49 & $46.9 \%$ \\
Relates to the nature of the business & 28 & $75.0 \%$ \\
User-side info adjustments & 24 & $58.3 \%$ \\
Other information & 21 & $81.0 \%$ \\
Application/measurement complexity & 19 & $5.3 \%$ \\
Other & 32 & $62.5 \%$ \\
\hline Total & 256 & $57.8 \%$ \\
\hline \hline
\end{tabular}

\section{Panel B: Representational Faithfulness}

Full Sample

(440 Verbal Responses)

\begin{tabular}{lcc} 
Rationale: & Verbal Responses & \%ositive Responses \\
\cline { 2 - 3 } Application/measurement complexity & 150 & $8.7 \%$ \\
Other managerial incentives & 53 & $1.9 \%$ \\
Managerial compensation & 45 & $0.0 \%$ \\
Auditing & 44 & $97.7 \%$ \\
Accounting standards complexity & 30 & $30.0 \%$ \\
Notes and mandated disclosures & 27 & $29.6 \%$ \\
External verification & 21 & $95.2 \%$ \\
Relates to managerial impact and/or control & 14 & $0.0 \%$ \\
Other & 38 & $50.0 \%$ \\
\hline Total & 440 & $28.0 \%$ \\
\hline
\end{tabular}

This table reports the most frequent rationales raised by investment professionals to justify their assessments of relevance (Panel A) or representational faithfulness (Panel B). Every rationale that is mentioned more than 10 times in the Full Sample is presented separately. All other rationales are aggregated under Other. 


\section{Table 5: Alternative Information Sources}

\begin{tabular}{lc}
\hline \hline & Full Sample \\
\hline Financial accounting & $34.8 \%$ \\
Quantitative information on business & $13.4 \%$ \\
Qualitative information on business & $13.7 \%$ \\
Competitors & $12.3 \%$ \\
Governance & $3.9 \%$ \\
Macroeconomic information & $2.5 \%$ \\
Information on management & $2.7 \%$ \\
Product market & $8.1 \%$ \\
Other & $8.5 \%$ \\
\hline Total & $100.0 \%$ \\
\hline \hline
\end{tabular}

This table reports investment professionals' allocations of a fictitious budget across alternative information sources. 


\section{Table 6: Treatment Effects by Line Item}

Panel A: Relevance

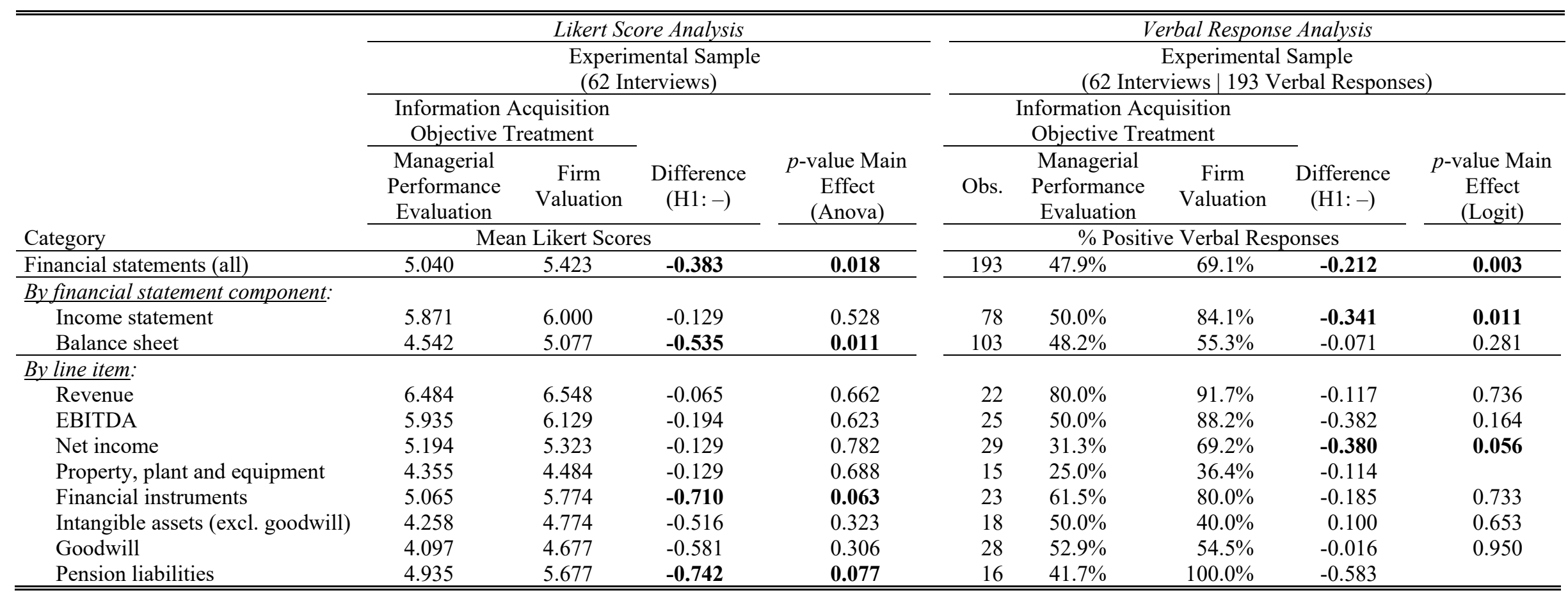


Table 6 (continued)

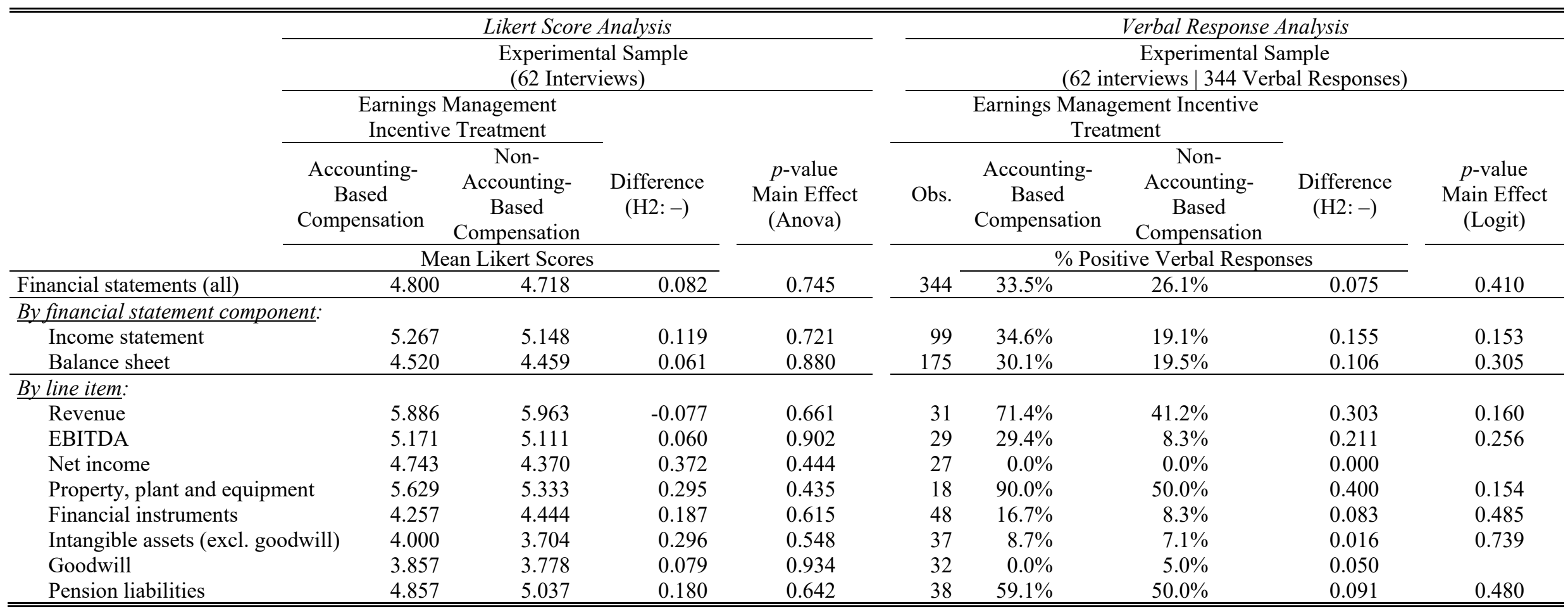

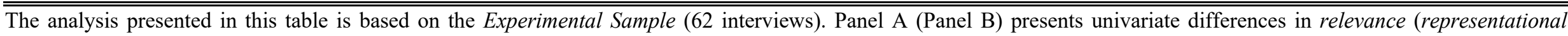

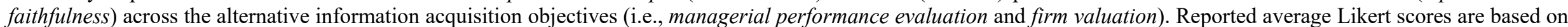

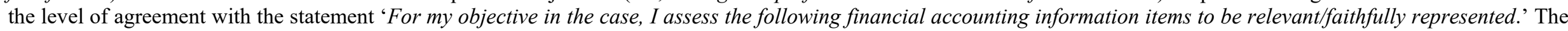

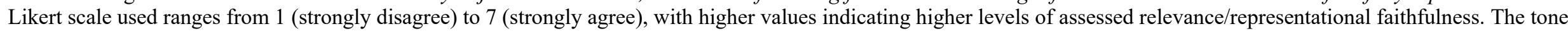

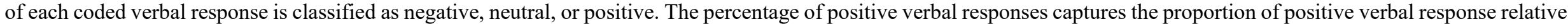

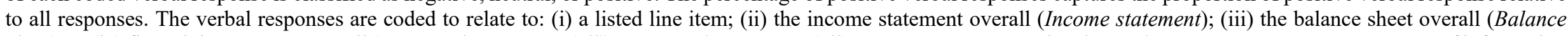

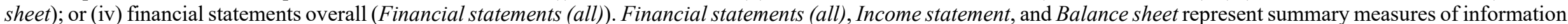

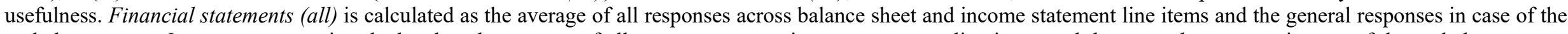

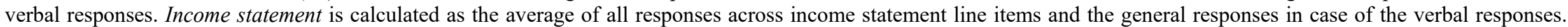

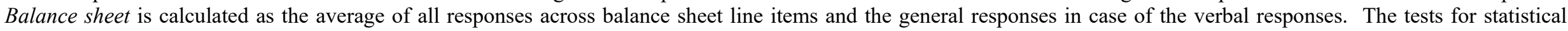

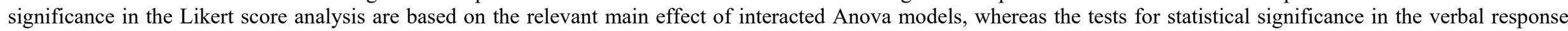

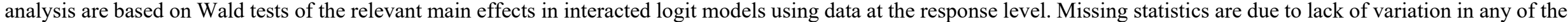
four condition cells. Statistically significant differences below the 10\% level (two-tailed) appear in bold print. 


\section{Table 7: Rationales Underlying Treatment Effects}

\section{Experimental Sample}

(193 Verbal Responses) Information Acquisition Objective Treatment

Rationale:

\begin{tabular}{|c|c|c|c|}
\hline \multicolumn{2}{|c|}{ Managerial Performance Evaluation } & \multicolumn{2}{|c|}{ Firm Valuation } \\
\hline Verbal Responses & $\begin{array}{l}\text { \% Positive } \\
\text { Responses }\end{array}$ & Verbal Responses & $\begin{array}{l}\text { \% Positive } \\
\text { Responses }\end{array}$ \\
\hline 14 & $50.0 \%$ & 45 & $64.4 \%$ \\
\hline 35 & $45.7 \%$ & 2 & $50.0 \%$ \\
\hline 3 & $33.3 \%$ & 15 & $86.7 \%$ \\
\hline 9 & $44.4 \%$ & 9 & $88.9 \%$ \\
\hline 7 & $57.1 \%$ & 13 & $92.3 \%$ \\
\hline 10 & $10.0 \%$ & 6 & $0.0 \%$ \\
\hline 18 & $72.2 \%$ & 7 & $57.1 \%$ \\
\hline 96 & $47.9 \%$ & 97 & $69.1 \%$ \\
\hline
\end{tabular}

Relevant for forecasting***

Relates to managerial impact and/or control***

Relates to the nature of the business ***

User-side info adjustments

Other information

Application/measurement complexity

Other

$47.9 \%$

\section{Panel B: Representational Faithfulness}

Experimental Sample
(344 Verbal Responses)

Earnings Management Incentive Treatment

\begin{tabular}{|c|c|c|c|c|}
\hline \multirow[b]{2}{*}{ Rationale: } & \multicolumn{2}{|c|}{ Non-Accounting-Based Compensation } & \multicolumn{2}{|c|}{ Accounting-Based Compensation } \\
\hline & Verbal Responses & \% Positive Responses & Verbal Responses & \% Positive Responses \\
\hline Application/measurement complexity** & 69 & $11.6 \%$ & 55 & $9.1 \%$ \\
\hline Other managerial incentives* & 14 & $7.1 \%$ & 26 & $0.0 \%$ \\
\hline Managerial compensation & 12 & $0.0 \%$ & 22 & $0.0 \%$ \\
\hline Auditing & 18 & $100.0 \%$ & 18 & $94.4 \%$ \\
\hline Accounting standards complexity & 11 & $27.3 \%$ & 16 & $37.5 \%$ \\
\hline Notes and mandated disclosures & 6 & $16.7 \%$ & 5 & $40.0 \%$ \\
\hline External verification & 7 & $100.0 \%$ & 11 & $100.0 \%$ \\
\hline Relates to managerial impact and/or control & 6 & $0.0 \%$ & 2 & $0.0 \%$ \\
\hline Other & 16 & $12.5 \%$ & 15 & $80.0 \%$ \\
\hline Total & 165 & $26.1 \%$ & 179 & $33.5 \%$ \\
\hline
\end{tabular}

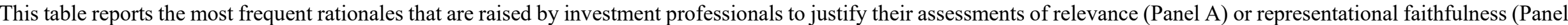

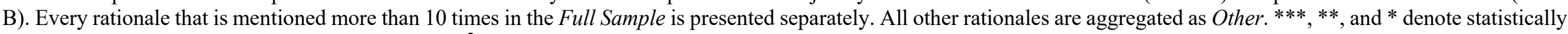
significant differences across treatments (based on $\chi^{2}$ tests) at the $1 \%, 5 \%$, and $10 \%$ levels (two-tailed), respectively. 


\section{Table 8: Treatment Effects for Relative Importance of Alternative Information Sources}

Panel A: Descriptive Statistics by Treatment

\begin{tabular}{|c|c|c|c|c|}
\hline & \multicolumn{4}{|c|}{ Experimental Sample } \\
\hline & \multicolumn{2}{|c|}{$\begin{array}{c}\text { Information Acquisition Objective } \\
\text { Treatment }\end{array}$} & \multicolumn{2}{|c|}{$\begin{array}{c}\text { Earnings Management } \\
\text { Incentive Treatment }\end{array}$} \\
\hline & $\begin{array}{c}\text { Managerial } \\
\text { Performance } \\
\text { Evaluation }\end{array}$ & $\begin{array}{l}\text { Firm } \\
\text { Valuation }\end{array}$ & $\begin{array}{l}\text { Accounting- } \\
\text { Based } \\
\text { Compensation } \\
\end{array}$ & $\begin{array}{c}\text { Non-Accounting- } \\
\text { Based } \\
\text { Compensation }\end{array}$ \\
\hline Financial accounting & $37.3 \%$ & $29.8 \%$ & $31.2 \%$ & $36.7 \%$ \\
\hline $\begin{array}{l}\text { Quantitative information on } \\
\text { business }\end{array}$ & $16.2 \%$ & $13.7 \%$ & $15.1 \%$ & $14.7 \%$ \\
\hline $\begin{array}{l}\text { Qualitative information on } \\
\text { business }\end{array}$ & $12.0 \%$ & $14.1 \%$ & $15.7 \%$ & $9.6 \%$ \\
\hline Competitors & $11.5 \%$ & $15.2 \%$ & $14.3 \%$ & $12.0 \%$ \\
\hline Governance & $2.8 \%$ & $5.1 \%$ & $2.1 \%$ & $6.4 \%$ \\
\hline Macroeconomic information & $1.5 \%$ & $2.9 \%$ & $0.6 \%$ & $4.3 \%$ \\
\hline Information on management & $4.2 \%$ & $1.0 \%$ & $4.4 \%$ & $0.2 \%$ \\
\hline Product market & $9.0 \%$ & $8.1 \%$ & $8.9 \%$ & $8.1 \%$ \\
\hline Other & $5.6 \%$ & $10.2 \%$ & $7.8 \%$ & $8.0 \%$ \\
\hline Total & $100.00 \%$ & $100.00 \%$ & $100.0 \%$ & $100.0 \%$ \\
\hline
\end{tabular}

Panel B: Treatment Effects

Experimental Sample

Dependent variable:

$\%$ Financial Accounting

Experimental treatment effects:

(A) Information acquisition objective:

$0.141 * *$

Managerial performance evaluation

$(0.023)$

(B) Earnings management incentive:

$-0.033$

Accounting-based compensation

$(0.574)$

(A) $\times(\mathrm{B})$

$-0.089$

$(0.364)$

$p$-value of test for main effect (A)

$\mathbf{0 . 0 3 2}$

$p$-value of test for main effect (B)

0.009

Obs. (interviews)

62

$\mathrm{R}^{2}$

0.095

This table reports the treatment effects for the additional information sources provided by investment professionals. Tests are conducted on the Experimental Sample (62 observations) using OLS estimation and bootstrapped standard errors (1,000 iterations) clustered by interviewer. The presented $p$-values for the experimental main effects are twotailed and based on Wald tests of the joint significance of the coefficients of the main effect of the regression above plus 0.5 times the interaction effect. Two-tailed $p$-values are reported in parentheses below the coefficients. ***,**, and $*$ denote statistical significance at the $1 \%, 5 \%$, and $10 \%$ levels (two-tailed), respectively. 
Table 9: Follow-Up Online Experiment

Panel A: Unconditional Inclusion Probabilities by Line Item

\begin{tabular}{lc}
\hline \hline Line Item & Inclusion Probability \\
\hline Other selling, general, and administrative expenses & $95.0 \%$ \\
Depreciation and amortization & $76.1 \%$ \\
Fair value gains on marketable securities (mark to market) & $13.6 \%$ \\
Fair value gains on unlisted equity instruments (mark to model) & $7.3 \%$ \\
Gains on revaluation of investment property & $9.1 \%$ \\
Interest expense & $76.8 \%$ \\
Taxation expense & $76.0 \%$ \\
\hline \hline
\end{tabular}

Panel B: Experimental Findings

\begin{tabular}{|c|c|c|}
\hline & \multicolumn{2}{|c|}{ Follow-Up Online Experiment Sample } \\
\hline & \multicolumn{2}{|c|}{$\begin{array}{c}\text { Dependent variable: } \\
\text { Delta Include }\end{array}$} \\
\hline & (1) & (2) \\
\hline Intercept & $\begin{array}{l}-0.032 * \\
(0.054)\end{array}$ & $\begin{array}{l}-0.028 \\
(0.152)\end{array}$ \\
\hline Experimental treatment effects: & & \\
\hline (A) Corporate governance Treatment: & $-0.038 * *$ & $-0.046^{*}$ \\
\hline Weak Governance Regime & $(0.047)$ & $(0.089)$ \\
\hline (B) Earnings management incentive: & -0.004 & -0.012 \\
\hline Accounting-based compensation & $(0.844)$ & $(0.653)$ \\
\hline$(\mathrm{A}) \times(\mathrm{B})$ & & $\begin{array}{l}0.017 \\
(0.662)\end{array}$ \\
\hline$p$-value of test for main effect (A) & & 0.046 \\
\hline$p$-value of test for main effect (B) & & 0.838 \\
\hline Obs. & 833 & 833 \\
\hline $\mathrm{R}^{2}$ & 0.005 & 0.005 \\
\hline
\end{tabular}

This table reports the findings of our follow-up online experiment using the Follow-Up Online Experimental Sample (833 observations). Panel A reports the unconditional inclusion probabilities for the line items included in the experiment. Panel B reports the treatment effects. The dependent variable Delta Include is the percentage point difference between: (i) the average of the inclusion probabilities for the line items Fair value gains on unlisted equity instruments (mark to model) and Gains on revaluation of investment property and (ii) the inclusion probability of the line item Fair value gains on marketable securities (mark to market). Because our subjects can either include (1) or not (0) a line item, Delta Include can vary between -1 and 1 with feasible values being $[-1,-0.5,0,0.5,1]$. Tests are conducted using OLS estimation. The presented $p$-values for the experimental main effects are two-tailed and based on Wald tests of the joint significance of the coefficients of the main effect of the regression above plus 0.5 times the interaction effect. Two-tailed $p$-values are reported in parentheses below the coefficients. $* * *, * *$, and $*$ denote statistical significance at the $1 \%, 5 \%$, and $10 \%$ levels (two-tailed), respectively. 


\section{ONLINE APPENDIX \\ The Usefulness of Financial Accounting Information: \\ Evidence from the Field}

\section{Details of the Survey Experiment}

The design of our survey experiment requires the construction of the case and the survey materials, including the experimental conditions used to treat our subjects. All e-mail templates used in correspondence, the ethical consent form, survey guidelines for the interviewers, case materials, and coding manual can be found in the paper's GitHub repository: https://github.com/joachimgassen/use fai.

\section{Development of Survey Experiment Materials}

The case materials are designed to balance the following objectives:

1. Generalizability: We select a manufacturing firm as representative of the most common types of firms in developed economies and one that we expect investment professionals to be familiar with. Moreover, the business model of a manufacturing firm is reasonably well reflected by financial accounting. To balance this industry choice, which might bias our findings towards higher overall usefulness of financial accounting information, we also include a portfolio of financial investments and a sizable level of intangible assets into the asset structure of our case firm. These line items are typically more relevant in other industries, like financial services, pharmaceuticals, or telecommunications.

2. Focus on core financial accounting information: Our research question assesses the usefulness of financial accounting information. Our case firm is private, which avoids the subjects referring to stock market information when assessing information usefulness. 
Furthermore, we exclude cash flow information from our case materials to avoid distracting the subjects from the balance sheet and income statement line items.

3. Variation in properties affecting assessments of relevance and representational faithfulness: We select line items with varying degrees of managerial discretion, informativeness about managerial activities, informativeness about firm value and financial accounting complexity because we expect these factors to affect the usefulness of financial accounting information.

4. Accessibility: Given the time constraints of our subjects, we design our survey experiment to be completed in around 45 minutes and mention this in our contact email. This includes the time that we expect our subjects to spend with the case materials. We therefore design the case materials with the expectation that it would take less than 5 minutes to process. The mean (median) processing time of the case material is 3 minutes and 12 seconds ( 2 minutes and 55 seconds). After the subject has read the case, the interviewer presents a summary of each paragraph of the case materials to the subject to make sure that $\mathrm{s} / \mathrm{he}$ understands the case materials. We encourage subjects to ask clarifying questions about the case materials (the occasional questions we receive show no systematic pattern).

The survey experiment design requires careful consideration of the likelihood that the subjects are treated, the structure of the case, and the characteristics of the subjects. To refine both the characteristics of the case materials and the features of the survey experiment conditions, we conduct two pre-tests involving graduate students and investment professionals.

\section{Pre-Test Phase with Standard Subjects: Graduate Students}

We pre-test our research design by conducting two paper-based and one online survey experiment involving 118 graduate students (Master's in Accounting and Finance students and MBA students from two UK universities, and MBA students from a German university). The results of these pre- 
tests are useful to understand whether the case materials are appropriate for standard subjects and whether the treatment is received by the subjects. We make marginal changes to the case and adjust the survey experiment design after the first pre-test phase.

\section{Pre-Test Phase with Non-standard Subjects: Investment Professionals}

After the first pre-test phase, we conduct two additional pre-test rounds with investment professionals. The first round involves six investment professionals and is used to finalize the case materials to ensure that these are appropriate for investment professionals. The second round, based on the final case, is used to finalize the experimental treatment. We pre-test our survey experiment design on five additional subjects. These subjects are included in our Full Sample of investment professionals, but excluded from the Experimental Sample. Following these five interviews, we increase the number of experimental conditions from two to four after recognizing that our initial instrument has not fully captured different dimensions of the uses of financial accounting information (our initial treatments were 'contracting' and 'valuation'; these combined components from both treatment arms were then decomposed to allow for a more detailed analysis of how investment professionals assess the relevance and representational faithfulness of accounting information under different conditions). We run descriptive statistics for the Experimental Sample. Univariate analyses based on the two samples available in the paper's GitHub repository reveal no qualitative differences between these groups.

\section{Identification of Investment Professionals}

We identify our subjects with the assistance of the Institute of Chartered Accountants of Scotland (ICAS) and the European Financial Reporting Advisory Group (EFRAG). This leads to an initial sample of 101 investment professionals. We approach our subjects via email. We mention only 
that our project involves an 'interview' for the purpose of collecting experienced investment professionals' views on the usefulness of financial accounting information. We generally obtain a positive response rate, with 88 of the approached investment professionals agreeing to schedule an interview, six of whom we use for the first pre-test round. Each investment professional then receives more detailed information regarding the research project and the members of the research team, but at no point are they informed of the specifics of the method used, or that they would be involved in a randomized survey experiment.

Before the start of each interview and after the interview ends, each investment professional is asked to read and, if agreeable, sign an ethical consent form. Only one subject does not agree to sign the consent form at the end of the interview and is therefore removed from the sample. Investment professionals are asked for permission to record their interviews to enable further analysis of their interview materials. Also, they are informed that any sensitive materials covered in the interviews and the response data would remain strictly confidential and that any results reported would not contain identifying information. Each interviewer uses an interview guideline to standardize data collection and minimize interviewer bias. Investment professionals only saw the text corresponding to their assigned condition, and no indication of treatment.

\section{Details of the Follow-Up Online Experiment ${ }^{1,2}$}

The investment professionals included in our follow-up online experiment are selected from the Eikon database. We retrieve the names, gender, email addresses, and contact-address country for all investment professionals in the database with the primary function 'Security Analyst,'

\footnotetext{
${ }^{1}$ The e-mail templates, online experiment (code and instrument), and illustrative examples of screenshots can be found in the paper's GitHub repository.

${ }^{2}$ Full results from the online experiment which allow the reader to download the data, and/or change the sample under analysis, can be accessed online in the paper's GitHub repository.
} 
'Associate Analyst,' or 'Portfolio Manager.' ${ }^{3}$ This process yields a total of 63,976 individual email addresses together with names and gender, after excluding 15 individuals who are included in the first experiment. To deliver the email, we partition our sample by two dimensions: 1) the geographic region where the investment professional is based (i.e., Europe, North America, and rest of the world), and 2) whether Eikon classifies the respective investment professional as a portfolio manager or a security analyst. When randomizing the sending order across the resulting 6 groups, we uniformly distribute all email domains with more than 100 recipients and all countries with more than 1,000 recipients to limit the load on individual domains and to ensure balanced email administration across time for observable covariates.

Leaving out the weekend of July $4^{\text {th }}, 2019$, we send emails over the period June $26^{\text {th }}, 2019$ to July $9^{\text {th }}, 2019$. We send an email every four seconds from 9:00AM to 7:00PM CEST every day, yielding 9,000 emails a day. Invalid email addresses and one domain asking to be excluded from receiving emails reduce the number of administered emails to 63,905 . We receive delivery failure notifications from 7,507 recipients, further reducing the number of successfully administered emails to 56,398. Based on the flow of responses, we stop collecting responses exactly one week after sending out the last email on July $16^{\text {th }}, 2019$.

We obtain 1,241 responses, a bounce-adjusted response rate of $2.2 \%$ (unadjusted response rate is $1.9 \%$ ). 1,115 do and 922 pass the manipulation checks. 1,105 start and 948 complete the assignment. 833 pass both manipulation checks and complete the assignment. While this is a low overall response rate, it is in line with prior studies that use comparable online instruments.

The administered email communicates the general purpose of the study, explains that the data would be treated anonymously (to encourage participation), and contains a link to the online

\footnotetext{
${ }^{3}$ When obtaining the data from Eikon, we discard names or email addresses of all portfolio managers whose secondary function indicates a passive investment approach.
} 
experiment. After clicking on the link, investment professionals are taken to the online experiment, which explains that their task is "to calculate adjusted earnings to assess firm performance" for a privately-held European firm operating in the manufacturing industry.

The data are collected in a server-side database together with timestamps. Cookies ensure that users are unable to complete the experiment more than once. As subjects are assured anonymity, we do not collect any data other than geographic region (North America, Europe, Rest of World) and type of occupation (Analyst or Portfolio Manager), which we gather from the stratification of the sample.

We use a $2 \times 2$ between subject design, where we manipulate, first, the corporate governance quality of the case firm, where investment professionals are informed either that the "corporate governance is assessed by external advisors to be strong compared to industry peers" or that "corporate governance is assessed by external advisors to be weak compared to industry peers." Second, we manipulate the earnings management incentives in the case firm, where investment professionals are informed that the firm bases managerial compensation either "on internal production targets" or "on net income."

Once investment professionals have reviewed this information, they proceed to our manipulation check, and then, to the task itself. This final screen allows investment professionals to select and de-select from a list of seven items that can be added to their adjusted earnings calculation, which for all cases, already includes Revenue and Cost of Goods Sold. At least one item has to be selected before the completed task can be submitted. 